\title{
Green Synthesis of Gold and Iron Nanoparticles for Targeted Delivery: An In Vitro and In Vivo Study
}

\author{
Beenish Khanzada, ${ }^{1,2}$ Nosheen Akthar $\mathbb{D}^{3},{ }^{3}$ Muhammad Zeeshan Bhatti ${ }^{\mathrm{D}},{ }^{3}$ \\ Hammad Ismail, ${ }^{4}$ Mohammed Alqarni, ${ }^{5}$ Bushra Mirza, ${ }^{2}$ Gomaa Mostafa-Hedeab $\mathbb{D}^{6,7}$ \\ and Gaber El-Saber Batiha ${ }^{8}$ \\ ${ }^{1}$ Institute of Biochemistry, University of Sindh, Jamshoro 76080, Pakistan \\ ${ }^{2}$ Department of Biochemistry, Quaid-i-Azam University, Islamabad 45320, Pakistan \\ ${ }^{3}$ Department of Biological Sciences, National University of Medical Sciences, Rawalpindi 46000, Pakistan \\ ${ }^{4}$ Department of Biochemistry and Biotechnology, University of Gujrat, Gujrat 50700, Pakistan \\ ${ }^{5}$ Department of Pharmaceutical Chemistry, College of Pharmacy, Taif University, P.O. Box 11099, Taif 21944, Saudi Arabia \\ ${ }^{6}$ Pharmacology Department \& Health Research Unit, Medical College, Jouf University, Sakakah, Saudi Arabia \\ ${ }^{7}$ Pharmacology Department, Faculty of Medicine, Beni-Suef University, Beni Suef, Egypt \\ ${ }^{8}$ Department of Pharmacology and Therapeutics, Faculty of Veterinary Medicine, Damanhour University, \\ Damanhour 22511, Egypt
}

Correspondence should be addressed to Nosheen Akthar; nosheenakhtar@numspak.edu.pk

Received 14 June 2021; Revised 14 October 2021; Accepted 25 October 2021; Published 23 November 2021

Academic Editor: Shahid Hussain

Copyright (c) 2021 Beenish Khanzada et al. This is an open access article distributed under the Creative Commons Attribution License, which permits unrestricted use, distribution, and reproduction in any medium, provided the original work is properly cited.

\begin{abstract}
Nanotechnology has vast applications in almost all fields of science and technology. The use of medicinal plants for the synthesis of metallic nanoparticles has gained much attention nowadays. In the current research work, six medicinal plants were used for the synthesis of gold nanoparticles (AuNPs) and iron nanoparticles (FeNPs). The synthesized nanoparticles were characterized by different techniques including UV-visible spectrophotometry, scanning electron microscopy (SEM), and Fourier transform infrared spectroscopy (FTIR). Furthermore, the activities of green synthesized nanoparticles were screened in vitro using, for example, antibacterial, antioxidant, cytotoxic, and DNA protection assays. Both FeNPs and AuNPs had spherical shapes with an average size less than $50 \mathrm{~nm}$ and were found to have good antimicrobial and nontoxic effects. Furthermore, FeNPs from Ficus microcarpa demonstrated high drug loading efficiency (65\%) as compared to an anti-inflammatory drug (diclofenac potassium, DFP). We also evaluated the drug delivery potential, as well as anti-inflammatory and anticoagulant properties, of nanoparticles in vivo. Interestingly, AuNPs of Syzygium cumini exhibited strong anti-inflammatory potential as compared to DFP and diclofenacloaded FeNPs of Ficus microcarpa. The results suggest potential pharmacological applications of biogenic synthesized AuNPs and FeNPs which can be explored further. The study revealed that the green synthesized AuNPs and FeNPs provide a promising approach for the synthesis of drug-loaded nanoparticles and consequently in the field of targeted drug delivery.
\end{abstract}

\section{Introduction}

Nanotechnology has gained much popularity nowadays in almost all fields of science and technology, because of its vast applications in medicine, chemistry, electronics, and engineering $[1,2]$. Various chemical, physical, and biological approaches are now being used for the synthesis of metallic nanoparticles [3, 4]. Chemical methods involve the use of toxic chemicals that not only pose a risk to the environment and human health but also have the problems of low stability and aggregation of particles [5]. Hence, the plant-based biological approach is considered ideal over other microbesmediated biological methods due to low cost, high reproducibility, eco-friendliness, less reaction time, and 
elimination of cell culture step [6-9]. Plant extracts contain many different kinds of phytochemicals that serve as strong reducing and stabilizing agents, which drive the synthesis of nanoparticles [10-12]. Therefore, the size, shape, and other properties of synthesized nanoparticles may vary depending on the nature and source of the plant being used [13]. Plant extract-based synthetic approach is widely reported in the literature $[14,15]$, but there is still a lot to be explored regarding the reduction potential of various phytochemicals because of the diversity and high potential of plants in producing nanoparticles of different sizes and shapes [16].

Phyllanthus emblica, Syzygium cumini, Mentha piperita, Rosa indica, Mallotus philippensis, and Ficus microcarpa are important medicinal plants of Pakistan. These plant extracts have been reported for significant pharmacologically effects, including anti-inflammatory, antitumor, hepatoprotective, antidiabetic, antioxidant, and antimicrobial activities [17-20]. Many studies have indicated that phytochemicals such as polyphenols, hydrolyzable tannins, flavonoids, alkaloids, terpenoids, and proteins present in these plant extracts are the major bioactive compounds responsible for their different biological activities [21, 22]. Phytochemicals are capable of reducing metal ions to nanoparticles but also help in their stabilization $[23,24]$.

In the present study six medicinal plants, Phyllanthus emblica, Syzygium cumini, Mentha piperita, Rosa indica, Mallotus philippensis, and Ficus microcarpa, were used to synthesize gold (AuNPs) and iron (FeNPs) nanoparticles of different morphology and biological activities. Nanoparticles were characterized by UV-visible spectrophotometry, scanning electron microscopy (SEM), and Fourier transform infrared spectroscopy (FTIR). Biological activities of AuNPs and FeNPs were evaluated in vitro by antibacterial assay, $\mathrm{DPPH}$ free radical scavenging assay. Nontoxic effects of nanoparticles were assessed by brine shrimp cytotoxicity assay and inhibition of hydroxyl free radical-induced DNA damage assay. To minimize the side effects, like gastric irritation due to high dose administration of nonsteroidal anti-inflammatory drugs like diclofenac potassium (DFP), we also developed a method to load DFP on green synthesized AuNPs and FeNPs coupled with folic acid for targeted diclofenac delivery. The efficacy of drug-loaded nanoparticles was assessed in vivo using the mouse model.

\section{Material and Methods}

2.1. Preparation of Gold and Iron Nanoparticles. A volume of $500 \mu \mathrm{L}, 1 \mathrm{~mL}, 2 \mathrm{~mL}$, and $4 \mathrm{~mL}$ of the aqueous leaf extract $(2 \mathrm{~g} /$ $100 \mathrm{~mL}$ ) was carefully added to $25 \mathrm{~mL}$ of $1 \mathrm{mM}$ aqueous chloroauric acid $\left(\mathrm{HAuCl}_{4}\right)$ and ferrous sulfate heptahydrate $\left(\mathrm{FeSO}_{4} .7 \mathrm{H}_{2} \mathrm{O}\right.$ ) (Sigma Aldrich Chemical Co., St. Louis, Mo, USA) solution. The flasks containing the mixture of extract and corresponding salts were incubated at $50^{\circ} \mathrm{C}$ for $24 \mathrm{~h}$ in the dark.

2.2. Characterization of Nanoparticles. All synthesized nanoparticles were characterized by the following techniques.
2.3. UV-Visible Spectroscopy Analysis. UV-visible spectrum of gold and iron nanoparticles was monitored by UV-visible spectroscopy (Agilent UV-visible spectrophotometer). Respective plant extract and salt solutions were used as controls. The measurement was carried out at wavelength ranges of 400-800 $\mathrm{nm}$ and $200-400 \mathrm{~nm}$ for characterization of gold and iron nanoparticles, respectively.

2.4. Scanning Electron Microscopy (SEM). The shape and size of nanoparticles were evaluated by SEM using an analytical scanning electron microscope (JSN, 6490A, Tokyo, Japan). Thin films of the nanoparticles were prepared on a carboncoated copper grid by simply dropping a very small amount of the sample on the grid, and excess solution was removed by blotting paper.

2.5. Fourier Transform Infrared Spectroscopy (FTIR). FTIR spectra of gold and iron nanoparticles were recorded in $\mathrm{KBr}$ pellets using a PerkinElmer spectrophotometer (Thermo Scientific, USA). The wavenumber range was selected in the range of middle infrared of $4000-400 \mathrm{~cm}^{-1}$. The peaks obtained were plotted as wavenumber $\left(\mathrm{cm}^{-1}\right)$ in $X$ axis and as percentage transmittance in $Y$-axis.

2.6. Temperature Dependent Stability of Nanoparticles. The biosynthesized nanoparticles were stored at $4^{\circ} \mathrm{C}$ and analyzed through UV-visible spectrophotometer for eight months for stability.

2.7. Antibacterial Assay. The antibacterial activity of green synthesized nanoparticles was evaluated by the disc diffusion method as described previously [25]. Seven bacterial strains, i.e., Bacillus subtilis (B. subtilis), Salmonella typhi (S. typhi), Enterobacter aerogenes (E. aerogenes), Pseudomonas septic (P. septica), Staphylococcus aureus (S. Aureus), Micrococcus luteus (M. Luteus), and Escherichia coli (E. coli), were used on nutrient agar plates. Sterile filter paper discs impregnated with $5 \mu \mathrm{L}$ of each nanoparticle solution with $20 \mu \mathrm{g} / \mathrm{mL}$, $10 \mu \mathrm{g} / \mathrm{mL}, 5 \mu \mathrm{g} / \mathrm{mL}$, and $2.5 \mu \mathrm{g} / \mathrm{mL}$ final concentration were placed on the seeded plates. Disc infused with Kanamycin (standard antibacterial) served as a positive control. Plates were incubated at $37^{\circ} \mathrm{C}$ for $24 \mathrm{~h}$. After incubation, the diameter of the zone of inhibition was measured with the help of the vernier caliper. Nanoparticles producing an inhibitory concentration (MIC) were determined by standard threefold broth microdilution method. A stock solution of each active nanoparticle was serially diluted in 96-well plates with Mueller Hinton broth. A standardized inoculum for each bacterial strain was prepared as an inoculum size of $5 \times 10^{4} \mathrm{CFU} /$ $\mathrm{mL}$ in each well. Then, plates were incubated at $37^{\circ} \mathrm{C}$ overnight. The MIC was calculated as the lowest concentration of the nanoparticles inhibiting the growth of bacterial strain by measuring OD at $600 \mathrm{~nm}$, and the assay was performed as triplicated analysis. 
2.8. DPPH Free Radical Scavenging Assay. The free radical scavenging activity of samples was determined by the reported method with some modifications [26]. Each nanoparticle sample $(10 \mu \mathrm{L})$ with final concentration of $100 \mu \mathrm{g} /$ $\mathrm{mL}, 50 \mu \mathrm{g} / \mathrm{mL}, 25 \mu \mathrm{g} / \mathrm{mL}$, and $12.5 \mu \mathrm{g} / \mathrm{mL}$ was mixed with $0.1 \mathrm{mM}$ DPPH $(190 \mu \mathrm{L})$ in 96 -well plate. Deionized water and ascorbic acid were used as negative and positive controls, respectively. The reaction was carried out in triplicate, and mixtures were incubated in the dark at $37^{\circ} \mathrm{C}$ for $30 \mathrm{~min}$. Following incubation, the absorbance of samples was measured at $517 \mathrm{~nm}$ using a microplate reader. $\mathrm{IC}_{50}$ was calculated by TableCurve software (version 4 ), and the free radical scavenging potential of the sample was calculated with the help of the following formula:

scavenging activity $(\%)=\left(\frac{1-\text { absorbance of sample }}{\text { absorbance of control }}\right) \times 100$.

2.9. Brine Shrimp Cytotoxicity Assay. Brine shrimp cytotoxic assay was used to assess the toxicity of nanoparticles [27]. Artemia salina (brine shrimp) eggs (Ocean Star Inc., USA) were hatched in seawater $(34 \mathrm{~g} / \mathrm{L})$. After $24 \mathrm{~h}$, shrimps were transferred to vials, with almost 15 in each vial. The test samples with the final concentrations of $50 \mu \mathrm{g} / \mathrm{mL}, 25 \mu \mathrm{g} / \mathrm{mL}$, and $12.5 \mu \mathrm{g} / \mathrm{mL}$ were added, and the final volume was made up to $5 \mathrm{~mL}$. The whole procedure was carried out in triplicate. The vials were kept under light at $25-28^{\circ} \mathrm{C}$ for $24 \mathrm{~h}$ of incubation. After $24 \mathrm{~h}$, surviving brine shrimps were counted by $3 \mathrm{x}$ magnifying glass. Percentage viability was calculated using the following formula:

$$
\text { percentage viability }=\left(\frac{\text { control }- \text { test }}{\text { control }}\right) \times 100 \text {. }
$$

2.10. Inhibition of Hydroxyl Free Radical-Induced DNA Damage Assay. DNA protection ability of nanoparticles against hydroxyl free radical-induced DNA damage was determined in vitro using a DNA protection assay [27]. The reaction was performed in PCR tubes with $16 \mu \mathrm{L}$ of the total volume having $4 \mu \mathrm{L}$ of pBR322 DNA $(0.5 \mu \mathrm{g}), 3 \mu \mathrm{L}$ of $2 \mathrm{mM}$ $\mathrm{FeSO}_{4}, 4 \mu \mathrm{L}$ of $30 \% \mathrm{H}_{2} \mathrm{O}_{2}$, and $5 \mu \mathrm{L}$ of nanoparticles with 1000,100 , and $10 \mu \mathrm{g} / \mathrm{mL}$ final concentrations. DNA of pBR322 treated with $2 \mathrm{mM} \mathrm{FeSO}_{4}$ and $30 \% \mathrm{H}_{2} \mathrm{O}_{2}$ was used as positive control while untreated pBR322 DNA served as negative control $(\mathrm{P})$. To check the effects of samples on DNA, prooxidant control containing the sample and untreated pBR322 was used. The mixtures were then incubated at $37^{\circ} \mathrm{C}$ for $1 \mathrm{~h}$. Reaction mixtures were run on $0.8 \%$ agarose gel electrophoresis in $1 \mathrm{x}$ TBE buffer using $1 \mathrm{~Kb}$ ladder $(L)$. The gel was visualized by using gel documentation system (Bio-Rad Laboratories, California, USA).

2.11. Preparation of Drug-Loaded Nanoparticles. DFP was loaded on green synthesized AuNPs and FeNPs of Syzygium cumini and Ficus microcarpa according to the reported method [28]. A stock solution of DFP $(10 \mathrm{mg} / \mathrm{mL})$ was prepared, in addition to further serial dilutions, i.e., $4 \mathrm{mg} /$ $\mathrm{mL}, 2 \mathrm{mg} / \mathrm{mL}$, and $1 \mathrm{mg} / \mathrm{mL}$. The concentration of drug to be used for loading was optimized by carrying out reactions of drug loading at the above concentrations. $2 \mathrm{~mL}$ of optimized concentration (e.g., $2 \mathrm{~mL}$ of $2 \mathrm{mg} / \mathrm{mL}$ drug) of the drug was added to $6 \mathrm{~mL}$ of AuNPs and FeNPs $(1 \mathrm{mg} / \mathrm{mL})$, and the mixture was allowed to stir for $24 \mathrm{~h}$ and then centrifuged at $14,000 \mathrm{rpm}$ for $30 \mathrm{~min}$. Drug-loaded nanoparticles were washed twice with deionized water. The pellet (that contains drug-loaded nanoparticles) was again dispersed in deionized water for characterization. Drug loading was evaluated by measuring the absorbance of supernatant and standard drug solution at $276 \mathrm{~nm}$. The efficiency of drug adsorption was calculated using the following formula:

$$
\% \text { loading efficiency }=\left(\frac{\text { drug added during preparation }- \text { drug in the supernatant }}{\text { amount of drug added during preparation }}\right) \times 100
$$

\subsection{Preparation of Diclofenac-Loaded Folic Acid Attached} Nanoparticles. $150 \mathrm{mg}$ of 1-ethyl-3-(3-dimethyl aminopropyl)carbodiimide (EDC) was dissolved in $2.5 \mathrm{~mL}$ of $0.1 \mathrm{M} \mathrm{NaOH}$, and $150 \mathrm{mg}$ of folic acid (FA) was added to the mixture and then activated for $3 \mathrm{~h}$. Casein $(500 \mathrm{mg})$ dissolved in $10 \mathrm{~mL}$ of $0.1 \mathrm{M} \mathrm{NaOH}$ was added to it and stirred for $24 \mathrm{~h}$. It was then dialyzed against water to obtain casein-folic acid conjugate and to remove unreacted EDC and folic acid from that conjugate. $1 \mathrm{~mL}$ of the conjugate was added to drug-loaded nanoparticles $(5 \mathrm{mg} / \mathrm{mL})$ and stirred for $12 \mathrm{~h}$, followed by centrifugation to synthesize drug-loaded folic acid attached nanoparticles. The free drug in the supernatant was determined by measuring its absorbance at $276 \mathrm{~nm}$.
2.13. Anti-Inflammatory Assay. The anti-inflammatory potential of nanoparticles was assessed by the carrageenaninduced mouse paw edema test as reported previously [29]. Rats were divided according to weight and marked with a specific number. Drug dose was given according to the weight of the rat. All samples were dissolved in DMSO at a concentration of $1 \mathrm{mg} / \mathrm{mL}$, DFP was used as the positive control, and DMSO was used as the negative control. Weighed rats were divided into groups $(n=7)$. Animals were fed orally by feeding tubes $60 \mathrm{~min}$ before carrageenan injection. $100 \mu \mathrm{L}$ of freshly prepared carrageenan was injected into sub-planar tissues of the left hind paw of each rat. Plethysmometer (Ugo Basile 7140) calculated the paw volume instantly before and after the carrageenan injection at 0 , 
1 , and $3 \mathrm{~h}$ intervals. Three readings were recorded at each time interval. The increase in paw volume for subsequent time intervals was calculated by the following formula:

$$
\text { percentage inhibition }=\left[\left(\frac{A-B}{A}\right) \times 100\right] \text {, }
$$

where $A$ is edema of control rats and $B$ is edema of treated rats.

2.14. Anticoagulant Assay. Nanoparticles were screened for their anticoagulant activity by the rat capillary method used previously to determine the time delay in clot formation after the treatment [30]. After $1 \mathrm{~h}$ of dosage, the rat-tail was pierced with the help of a lancet, and the tail blood was filled in capillary tubes and placed in a water bath at $37^{\circ} \mathrm{C}$. After $60 \mathrm{~s}$, the small parts of the capillary tube were fragmented each $10 \mathrm{~s}$ until the thread of fibrin is visualized between the pierced ends of the tube. Aspirin was used as the positive control, and saline in 10\% DMSO served as the negative control. Clot formation time was measured in seconds, and the ratios were calculated using International Normalized Ratios [31]. The INR values were calculated by the following formula:

$$
\mathrm{INR}=\left(\frac{\mathrm{PT} \text { sample }}{\text { PT control }}\right)^{\text {ISI }} \text {. }
$$

In this equation, PT represents the prothrombin time (clotting time) and ISI represents the international sensitivity index as per WHO guidelines.

2.15. Statistical Analysis. The data were analyzed statistically by one-way analysis of variance (ANOVA) followed by Tukey's test using GraphPad Prism 8.0 software. Results are expressed as mean $\pm \mathrm{SD}$, and $p<0.05$ is considered significant.

\section{Results and Discussion}

3.1. Biosynthesis and Characterization of Gold and Iron Nanoparticles. In this study, gold and iron nanoparticles were synthesized from six different medicinal plants, i.e., Phyllanthus emblica, Syzygium cumini, Mentha piperita, Rosa indica, Mallotus philippensis, and Ficus macrocarpa, to check the comparative potential and efficacy of these strong antioxidant plants in the synthesis of nanoparticles. We already evaluated the comparative antioxidant activities of the plants [32]. In the current study, different concentrations of each plant extract were mixed with the solution of $\mathrm{HAuClO}_{4}$ and $\mathrm{FeSO}_{4} \cdot 7 \mathrm{H}_{2} \mathrm{O}$, incubated for $12-24 \mathrm{~h}$. Change in color of solution, purple/ violet and black/brown, indicated the synthesis of gold and iron nanoparticles, respectively (Figures 1(a) and 1(b)). UV-visible spectrophotometric analysis revealed characteristic peaks of gold nanoparticles at $541 \mathrm{~nm}$ and iron nanoparticles at $215 \mathrm{~nm}$ (Figure 1(c)). Metal salts and extracts (used as controls) did not show peak at characteristic nanoparticle wavelength. Sharp characteristic peaks of nanoparticles were observed at the optimal concentration of each extract. Stability studies of nanoparticles showed that most of the green synthesized gold and iron nanoparticles were found to be stable for eight months (Figure 1(d)). Only Phyllanthus emblica and Syzygium cumini gold nanoparticles showed a redshift indicating poor stability, while in the case of iron nanoparticles there was some change in the peak wavelength of Mallotus philippensis and Ficus microcarpa. Any redshift in surface plasmon resonance band may be due to an increase in either nanoparticle size, particle aggregation, or both. Moreover, the poor stability of these particles may be due to an increase in particle size and aggregation over time $[33,34]$. SEM analysis of green synthesized gold and iron nanoparticles revealed the uniform texture, small size (less than $50 \mathrm{~nm}$ ), and spherical shape of nanoparticles (Figure 2(a)). The AuNPs of Mallotus philippensis and FeNPs of Rosa indica exhibited the smallest size (i.e., $29 \mathrm{~nm}$ and $28 \mathrm{~nm}$, respectively). This is because of the different reduction capacities of each plant extract. The volume of extract used for nanoparticle synthesis also affects nanoparticle size [24, 33, 35]. SEM images also revealed that AuNPs have less agglomeration than FeNPs. This might be due to the magnetic behavior of iron nanoparticles and their larger surface area to volume ratio, as they tend to aggregate to reduce surface energy. These particles can be coated with a biocompatible polymer to remove agglomeration [36, 37]. The major plant biomolecules responsible for the reduction, stabilization, and capping of AuNPs and FeNPs were further verified by FTIR spectroscopy. The disappearance of characteristic functional group peak of plant extract in spectra of nanoparticles (both gold and iron) showed that these functional groups are involved in the synthesis of nanoparticles [38, 39]. Any shift in the peak of functional groups shows their involvement in the capping of nanoparticles. Considering this, FTIR spectra of all green synthesized nanoparticles were interpreted as shown in Table 1. Results showed the involvement of phytochemicals of plant extracts such as phenolics, alkaloids, flavonoids, and proteins in the synthesis and stability of nanoparticles. Some representative FTIR spectra are shown in Figure 2(b).

3.2. Antibacterial Activity. Antibacterial activity of green synthesized AuNPs and FeNPs was assessed by using disc diffusion assay. Plant extracts and metal salts used for metallic nanoparticles synthesis were used as controls. Initial screening was done at $20 \mu \mathrm{g} / \mathrm{mL}$. To calculate minimum inhibitory concentration (MIC), $10 \mu \mathrm{g} / \mathrm{mL}, 5 \mu \mathrm{g} / \mathrm{mL}$, and $2.5 \mu \mathrm{g} / \mathrm{mL}$ concentrations of nanoparticles were used. Our results showed that most of the AuNPs and FeNPs exhibited strong antibacterial activity against two Gram-positive strains ( $S$. aureus and $M$. luteus) and one gram -ve strain (E. aerogenes) with very low MIC value, i.e., $2.5 \mu \mathrm{g} / \mathrm{mL}$ (Figure 3(a)). At high concentrations, gold nanoparticles of Ficus microcarpa and Phyllanthus emblica significantly inhibited the growth of E. coli (gram -ve strain). Previous 

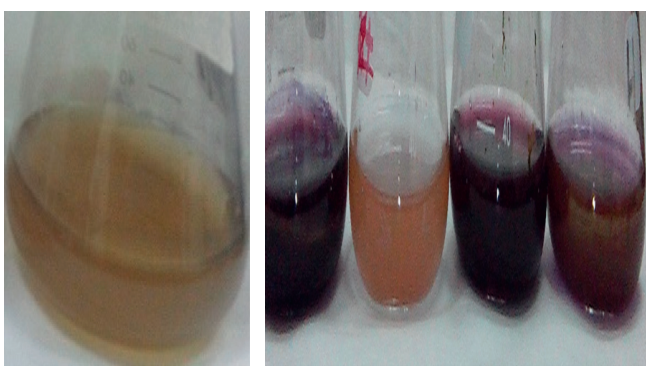

(a)
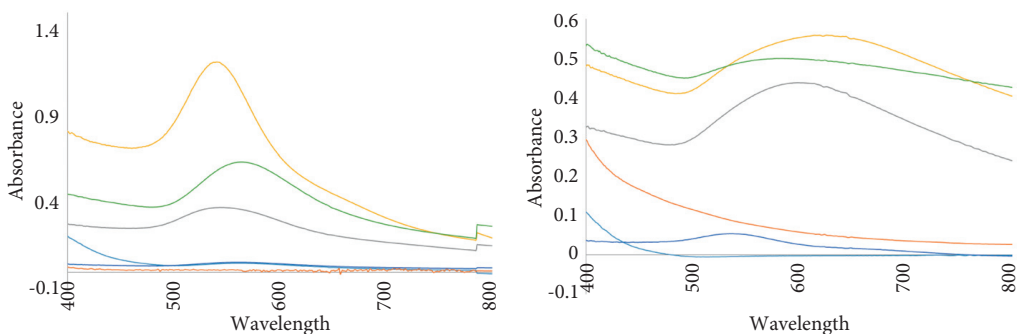

— Salt

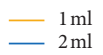

(A)

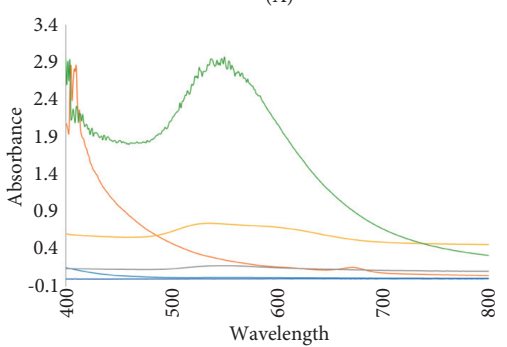

$$
\begin{aligned}
& \text { — salt } \\
& \text { - extract } \\
& \hline \quad 500 \mathrm{ul}
\end{aligned}
$$

$$
\begin{array}{r}
1 \mathrm{ml} \\
-\quad 2 \mathrm{ml}
\end{array}
$$

(D)
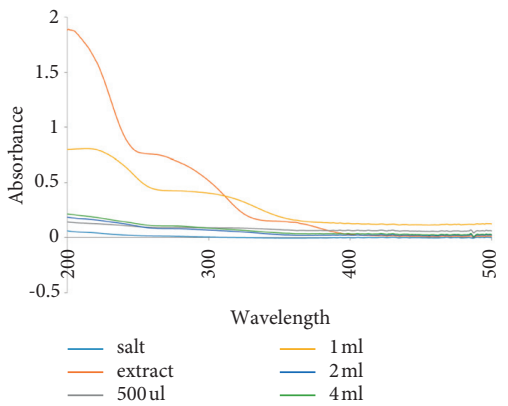

(G)

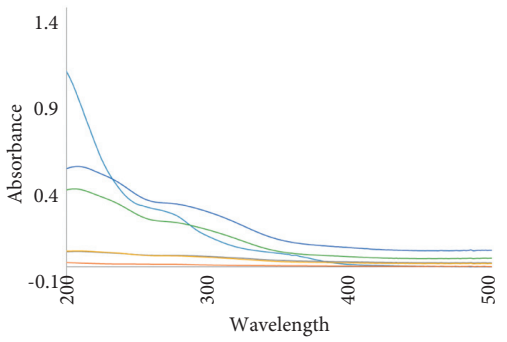

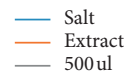

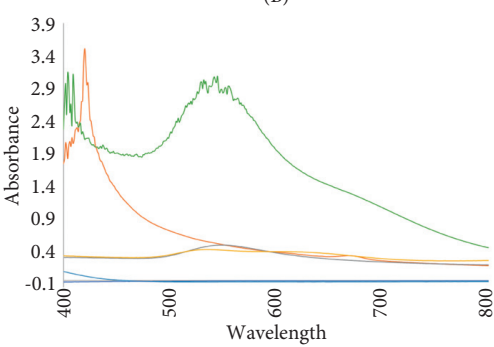

$1 \mathrm{ml}$
$-\quad 2 \mathrm{ml}$

(E)

(H)

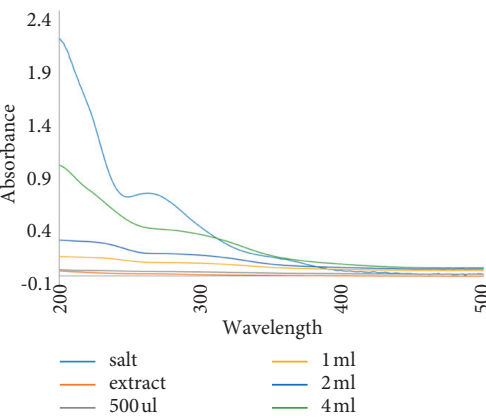

(K)

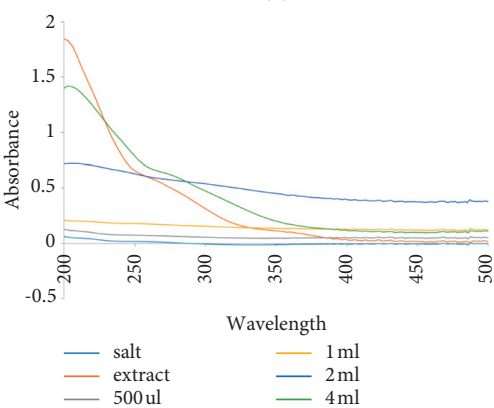

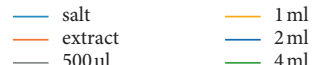

(J)
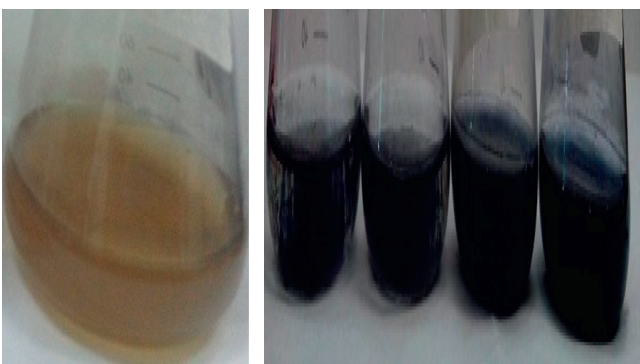

(b)

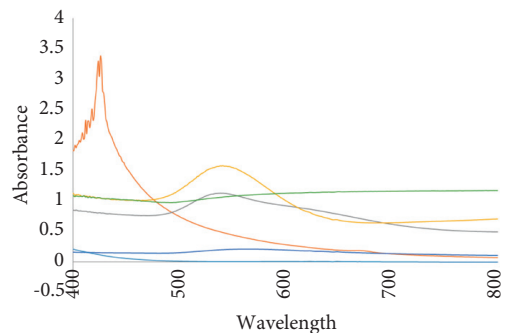

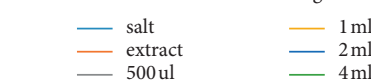

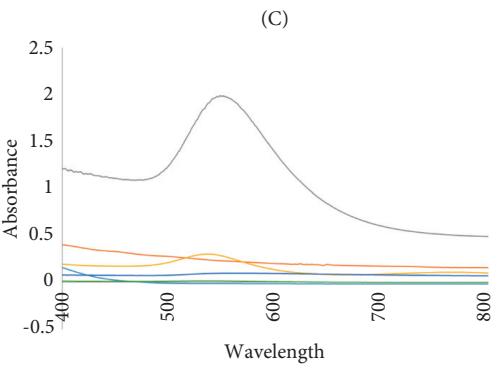

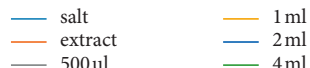

(F)

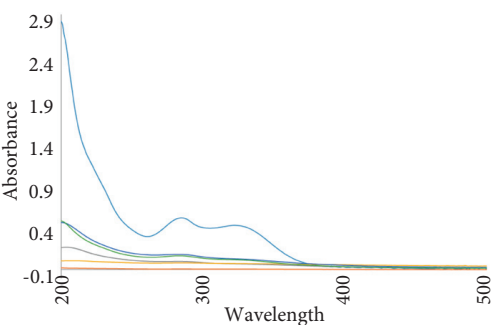

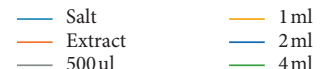

(I)

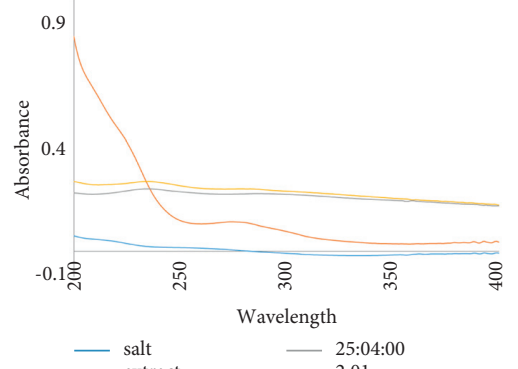

(L)

(c)

FIgURE 1: Continued. 


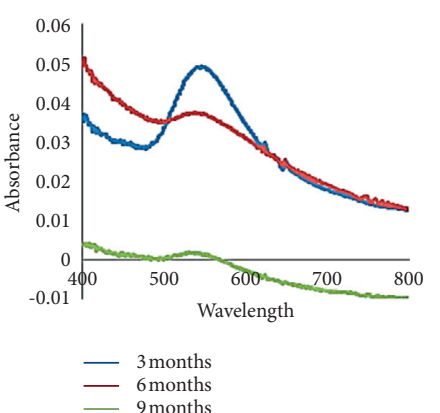

(A)
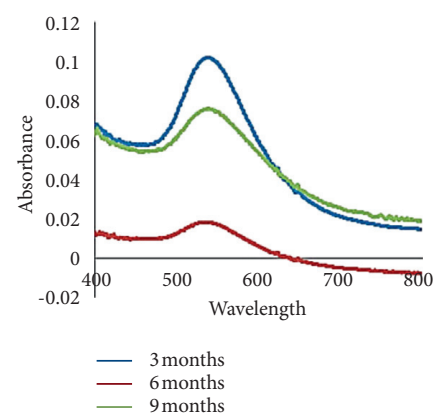

(D)

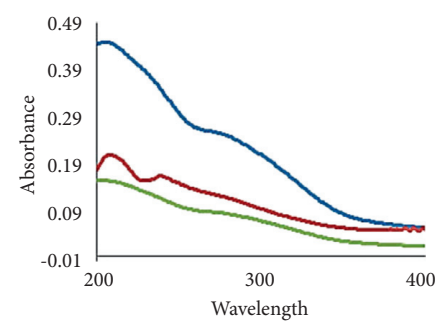

- 3 months

6months
$-\quad 9$ months

(G)

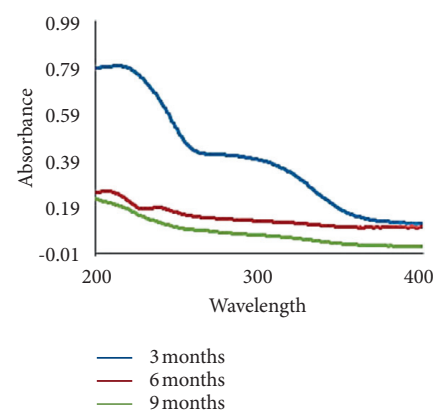

(J)

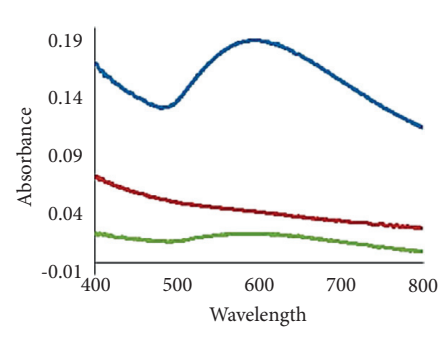

- 3 months

— 6 months

(B)
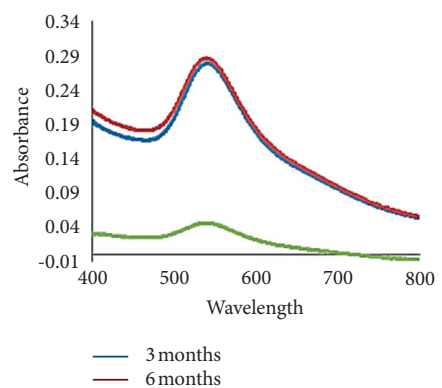

6 months
$-\quad 9$ months

(E)

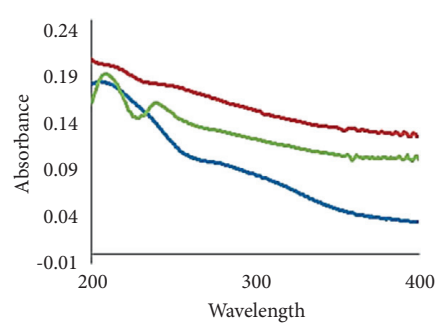

- 3 months
- 6 months

— 6 months

(H)

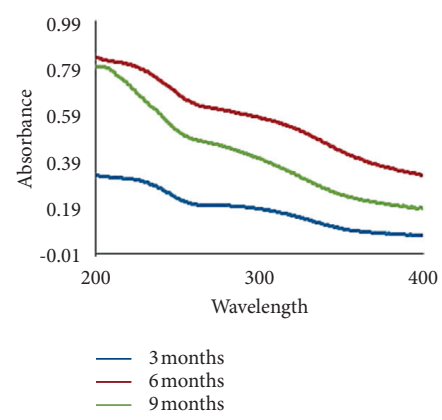

(K)

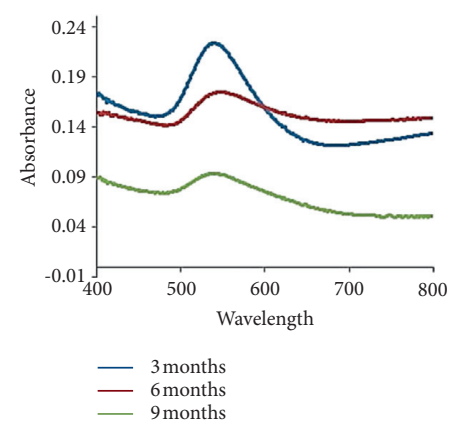

(C)

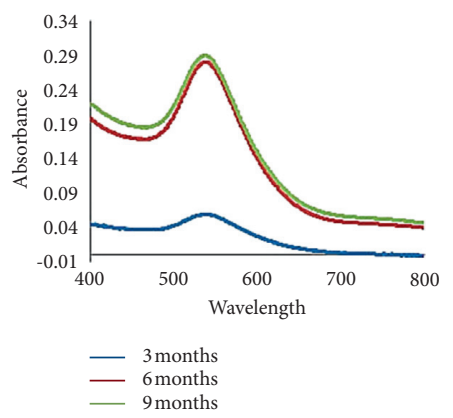

(F)

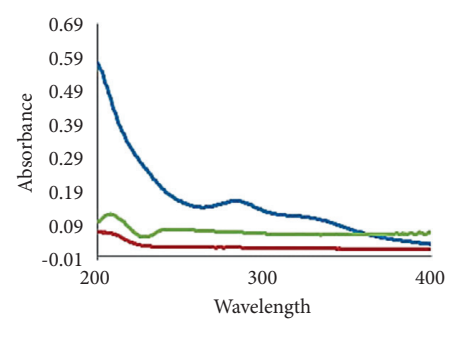

3 months
$-\quad 6$ months

— 6 months

(I)

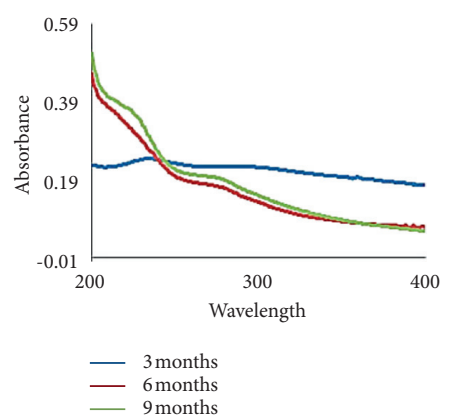

(L)

(d)

FIGURE 1: (a) Color change of extract showing the synthesis of different gold nanoparticles (AuNPs). (b) Color change of extract showing the synthesis of different iron nanoparticles (FeNPs). (c) UV-visible spectrum of (A) Phyllanthus emblica AuNPs (P. emblica AuNPs), (B) Syzygium cumini (AuNPs) (S. cumini AuNPs), (C) Mentha piperita AuNPs (M. piperita AuNPs), (D) Rosa indica AuNPs (R. indica AuNPs), (E) Mallotus philippensis AuNPs (M. philippensis AuNPs), (F) Ficus microcarpa AuNPs (F. microcarpa AuNPs), (G) Phyllanthus emblica FeNPs (P. emblica FeNPs), (H) Syzygium cumini FeNPs (S. cumini FeNPs), (I) Mentha piperita FeNPs (M. piperita FeNPs), (J) Rosa indica FeNPs (R. indica FeNPs), (K) Mallotus philippensis FeNPs (M. philippensis FeNPs), (L) Ficus microcarpa FeNPs (F. microcarpa FeNPs). (d) UV-visible spectrum showing stability of (A) P. emblica AuNPs, (B) S. cumini AuNPs, (C) M. piperita AuNPs, (D) R. indica AuNPs, (E) M. philippensis AuNPs, (F) F. microcarpa AuNPs, (G) P. emblica FeNPs, (H) S. cumini FeNPs, (I) M. piperita FeNPs, (J) R. indica FeNPs, (K) M. philippensis FeNPs, (L) F. microcarpa FeNPs. 

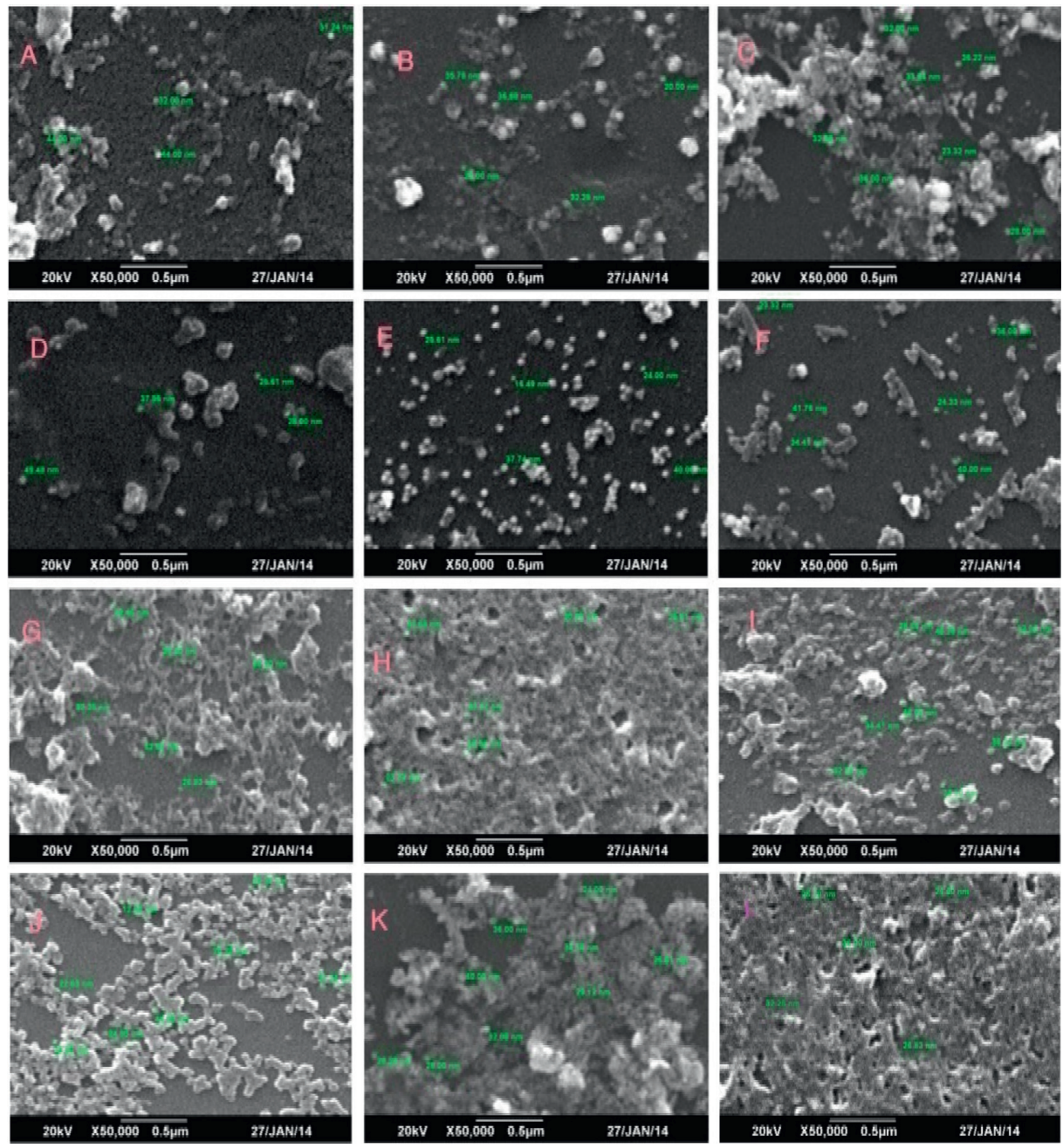

(a)
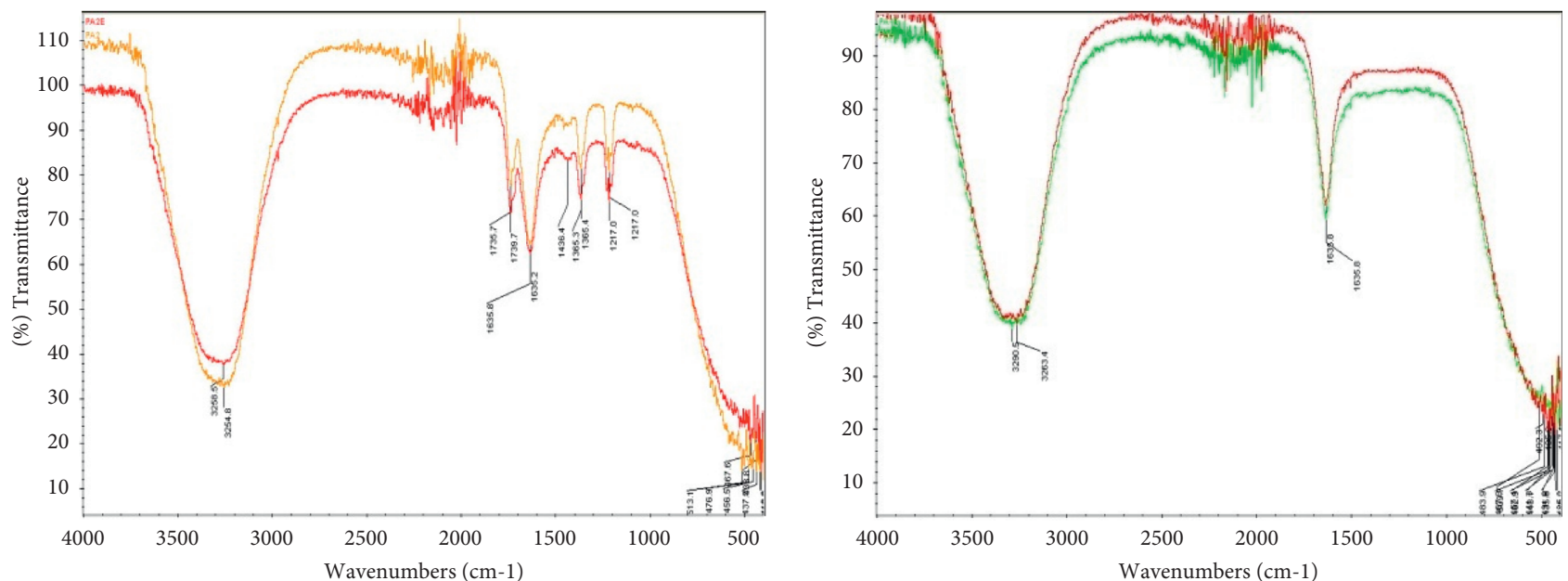

(b)

Figure 2: (a) SEM images of (A) P. emblica AuNPs, (B) S. cumini AuNPs, (C) M. piperita AuNPs, (D) R. indica AuNPs, (E) M. philippensis AuNPs, (F) F. microcarpa AuNPs, (G) P. emblica FeNPs, (H) S. cumini FeNPs, (I) M. piperita FeNPs, (J) R. indica FeNPs, (K) M. philippensis FeNPs, (L) F. microcarpa FeNPs. (b) FTIR spectra of (A) S. cumini AuNPs and S. cumini extract, (B) F. microcarpa AuNPs and F. microcarpa extract. 
TABLE 1: Interpretation of FTIR results.

\begin{tabular}{|c|c|c|c|}
\hline SN & $\begin{array}{c}\text { Type of } \\
\text { nanoparticles }\end{array}$ & $\begin{array}{l}\text { Reducing agents of plant extracts involved in } \\
\text { nanoparticle synthesis }\end{array}$ & $\begin{array}{l}\text { Capping agents of plant extracts involved in stabilizing } \\
\text { nanoparticles }\end{array}$ \\
\hline 1 & P. emblica AuNPs & Aldehyde/ketone containing phytochemicals & $\begin{array}{l}\text { 1. Polyphenols } \\
\text { 2. Flavonoids } \\
\text { 3. Proteins } \\
\text { 4. Alkaloids }\end{array}$ \\
\hline 2 & S. cumini AuNPs & $\begin{array}{l}\text { Alcohols and aromatic rings containing } \\
\text { phytochemicals }\end{array}$ & $\begin{array}{l}\text { 1. Polyphenols } \\
\text { 2. Proteins } \\
\text { 1. Polyphenols }\end{array}$ \\
\hline 3 & M. piperita AuNPs & Alkyl halide containing phytochemicals & $\begin{array}{l}\text { 2. Flavonoids } \\
\text { 3. Proteins }\end{array}$ \\
\hline 4 & R. indica AuNPs & Alcohols and phenols containing phytochemicals & $\begin{array}{l}\text { 1. Carboxylic acid } \\
\text { 2. Amides containing phytochemicals }\end{array}$ \\
\hline 5 & $\begin{array}{l}\text { M. philippensis } \\
\text { AuNPs }\end{array}$ & Alcohols and phenols containing phytochemicals & $\begin{array}{l}\text { 1. Proteins } \\
\text { 2. Polyphenols }\end{array}$ \\
\hline 6 & $\begin{array}{l}\text { F. microcarpa } \\
\text { AuNPs }\end{array}$ & Alkyl halides containing phytochemicals & $\begin{array}{l}\text { 1. Polyphenols } \\
\text { 2. Proteins } \\
\text { 1. Polyphenols }\end{array}$ \\
\hline 7 & P. emblica FeNPs & Aldehyde/ketone containing phytochemicals & $\begin{array}{l}\text { 2. Benzoid compound } \\
\text { 3. Flavonoids }\end{array}$ \\
\hline 8 & S. cumini FeNPs & Polyphenols & $\begin{array}{l}\text { 1. Polyphenols } \\
\text { 2. Flavonoids }\end{array}$ \\
\hline 9 & M. piperita FeNPs & Polyphenols aromatic ring containing phytochemicals & $\begin{array}{l}\text { 1. Proteins } \\
\text { 2. Polyphenols }\end{array}$ \\
\hline 10 & R. indica FeNPs & Proteins polyphenols & $\begin{array}{l}\text { 1. Proteins } \\
\text { 2. Polyphenols }\end{array}$ \\
\hline 11 & $\begin{array}{l}\text { M. philippensis } \\
\text { FeNPs }\end{array}$ & Flavonoids tannins & $\begin{array}{l}\text { 1. Polyphenols } \\
\text { 2. Proteins } \\
\text { 3. Alkaloids }\end{array}$ \\
\hline 12 & F. microcarpa FeNPs & $\begin{array}{l}\text { Nitro group and alkyl halide containing } \\
\text { phytochemicals }\end{array}$ & $\begin{array}{l}\text { 1. Proteins } \\
\text { 2. Polyphenols }\end{array}$ \\
\hline
\end{tabular}

P. emblica AuNPs: Phyllanthus emblica gold nanoparticles, S. cumini AuNPs: Syzygium cumini gold nanoparticles, M. piperita AuNPs: Mentha piperita gold nanoparticles, R. indica AuNPs: Rosa indica gold nanoparticles, M. philippensis AuNPs: Mallotus philippensis gold nanoparticles, F. microcarpa AuNPs: Ficus microcarpa gold nanoparticles, P. emblica FeNPs: Phyllanthus emblica iron nanoparticles, S. cumini FeNPs: Syzygium cumini iron nanoparticles, M. piperita FeNPs: Mentha piperita iron nanoparticles, R. indica FeNPs: Rosa indica iron nanoparticles, M. philippensis FeNPs: Mallotus philippensis iron nanoparticles, F. microcarpa FeNPs: Ficus microcarpa iron nanoparticles.

reports showed that AuNPs and FeNPs have more bactericidal effects for gram -ve bacteria than for gram +ve ones due to the thick peptidoglycan cell wall $[40,41]$. In the current study, green synthesized nanoparticles showed more or less the same antibacterial effect against both strains. The effect might be due to their small size, which enabled them to penetrate into the thicker wall of gram +ve bacteria, as well. Literature shows that gold nanoparticles may kill bacteria either by changing the membrane permeability, decreasing ATP levels by inhibition of ATP synthase, or inhibiting the binding of tRNA ribosomal subunit $[42,43]$. On the other hand, iron nanoparticles might exhibit bactericidal effects by inducing reactive oxygen species that may cause damage in the protein and DNA of the bacteria through oxidative stress $[44,45]$.

3.3. DPPH Free Radical Scavenging Activity. Free radical scavenging potential of nanoparticles was evaluated by $\mathrm{DPPH}$ assay at concentrations of $100 \mu \mathrm{g} / \mathrm{mL}, 50 \mu \mathrm{g} / \mathrm{mL}$, $25 \mu \mathrm{g} / \mathrm{mL}$, and $12.5 \mu \mathrm{g} / \mathrm{mL}$. Among plant extracts and metal salts, Phyllanthus emblica extract and iron salt showed significant free radical scavenging potential having $\mathrm{IC}_{50}$ values of $10.6 \mu \mathrm{g} / \mathrm{mL}$ and $18.9 \mu \mathrm{g} / \mathrm{mL}$, respectively. Gold nanoparticles synthesized in this study have not shown free radical scavenging potential except Phyllanthus emblica and Syzygium cumini gold nanoparticles, which showed antioxidant potential at a higher concentration of $200 \mu \mathrm{g} / \mathrm{mL}$ (Figure 3(b)). This is contrary to most of the reported studies, which showed the good antioxidant potential of gold nanoparticles [42, 46]. This may be because of some structural differences in these gold nanoparticles [40]. It is quite interesting to note that, among the six iron nanoparticles, Phyllanthus emblica and Syzygium cumini iron nanoparticles possess good free radical scavenging power with $\mathrm{IC}_{50}$ values $\leq 100 \mu \mathrm{g} / \mathrm{mL}$. This may be due to the very low $\mathrm{IC}_{50}$ values of these extracts as compared to other extracts. The antioxidant property of iron nanoparticles could be due to capping antioxidants (from extract) as well as due to ferrous salt being a good antioxidant.

3.4. Cytotoxic Activity. To evaluate nontoxic behavior, the investigated nanoparticles were subjected to brine shrimp cytotoxic assay. The results indicated a nontoxic effect of gold and iron nanoparticles with $100 \%$ viability 


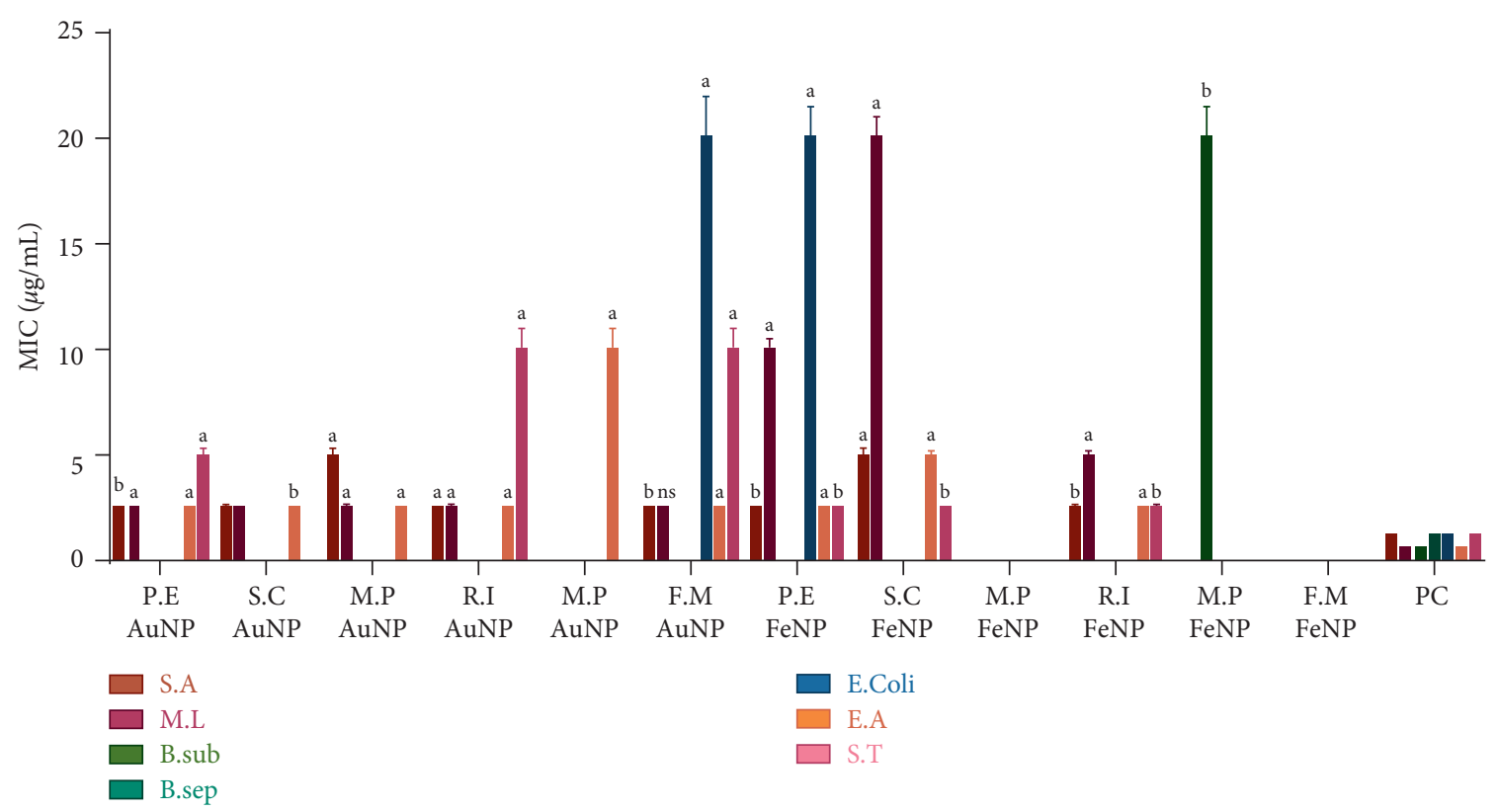

(a)

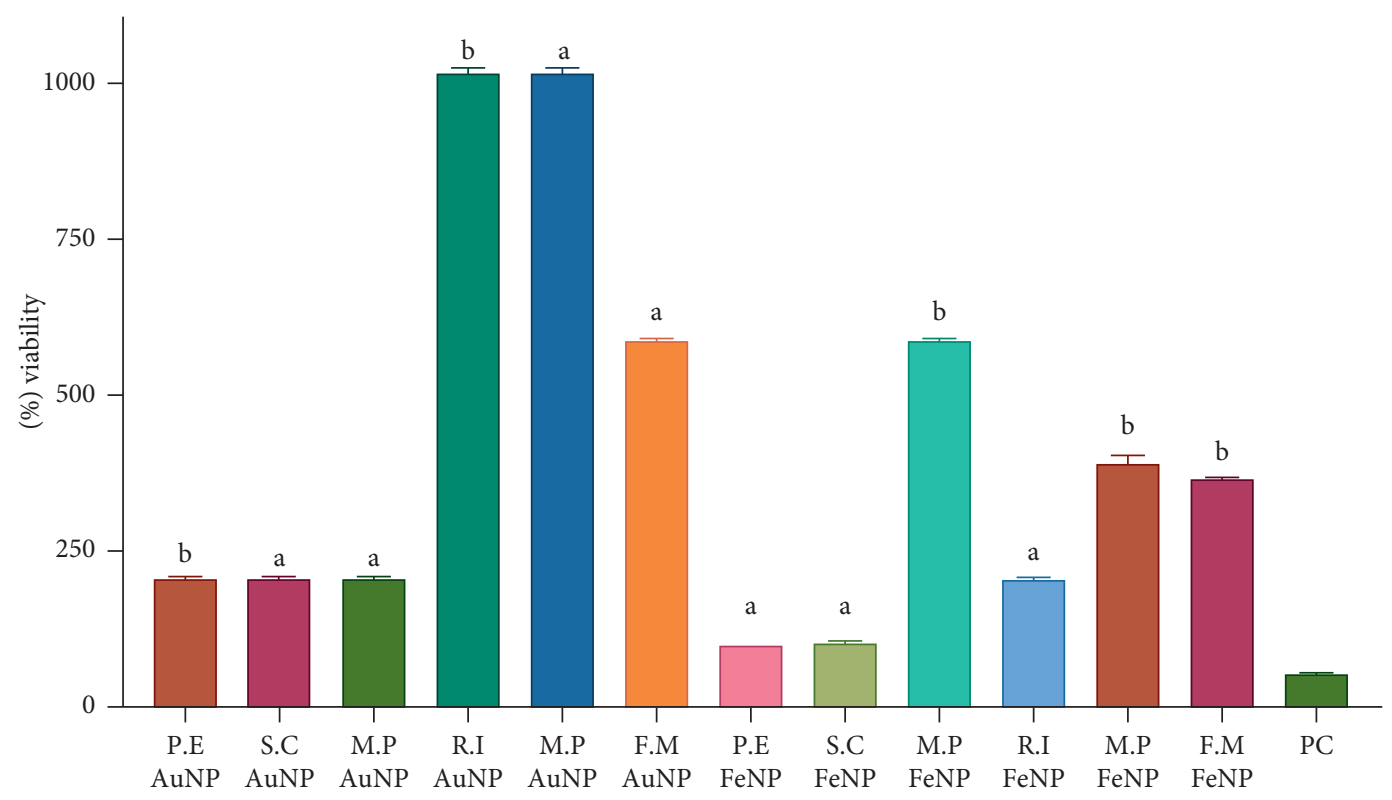

(b)

Figure 3: Continued. 


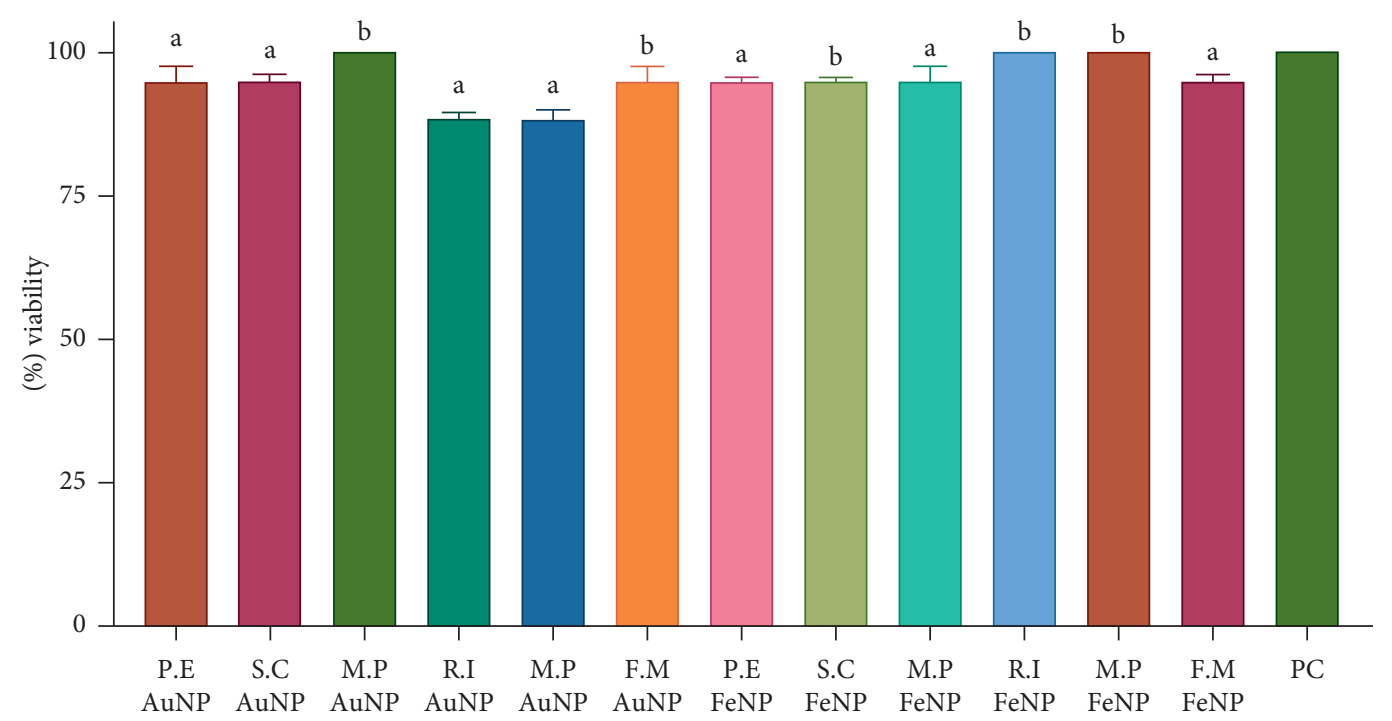

(c)

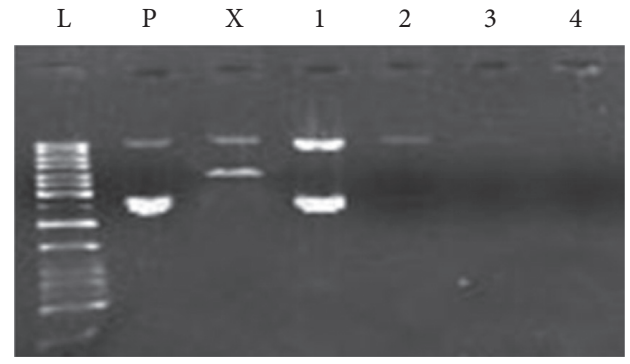

(A)

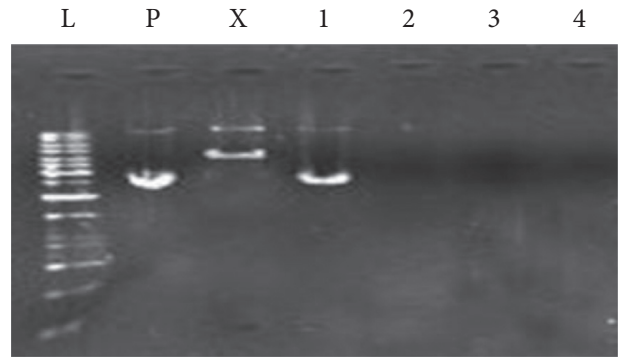

(B)

(d)

Figure 3: (a) Minimum inhibitory concentration of gold and iron nanoparticles against bacterial strains; S.A Staphylococcus aureus, M.L Micrococcus luteus, B. sub Bacillus subtilis, B. sep Bacillus septica, E. coli Escherichia coli, E.A Enterobacter aerogenes, S.T Staphylococcus aureus. (b) IC50 values of antioxidant potential of gold iron nanoparticles (FeNPs and AuNPs) assessed by DPPH free radical scavenging assay. (c) Brine shrimp cytotoxic assay, percent viability of brine shrimps at $50 \mu \mathrm{g} / \mathrm{mL}$ dose of gold and iron nanoparticles (FeNPs and AuNPs). (d) (A) DNA damage assay of gold nanoparticles (AuNPs), (B) DNA damage assay of iron nanoparticles (FeNPs); L: DNA ladder $\left(1 \mathrm{~Kb}\right.$ ), P: pBR322 plasmid, X: pBR322 plasmid treated with $\mathrm{FeSO}_{4}$ and $\mathrm{H}_{2} \mathrm{O}_{2}$ (positive control), 1: pBR322 plasmid $+1000 \mu \mathrm{g} / \mathrm{mL}$ of nanoparticles, control for the prooxidant effect, 2 : plasmid $+1000 \mu \mathrm{g} / \mathrm{mL}$ of nanoparticles $+\mathrm{FeSO}_{4}+\mathrm{H}_{2} \mathrm{O}_{2}, 3:$ plasmid $+100 \mu \mathrm{g} / \mathrm{mL}$ of nanoparticles $+\mathrm{FeSO}_{4}+\mathrm{H}_{2} \mathrm{O}_{2}$, 4: plasmid $+10 \mu \mathrm{g} / \mathrm{mL}$ of nanoparticles $+\mathrm{FeSO}_{4}+\mathrm{H}_{2} \mathrm{O}_{2}$. Data represent the mean of triplicate with statistical significance a: $p<0.001$, b: $p<0.01$.

(Figure 3(c)). The results are consistent with the reported findings that metal oxide nanoparticles (such as iron oxide particles) form agglomerates of size up to $400 \mathrm{~nm}$ that cannot be ingested by Artemia salina larvae, and thus these particles accumulate in the gut but do not cause mortality for exposure of $24 \mathrm{~h}[47,48]$.

\subsection{Inhibition of Hydroxyl $(\mathrm{OH})$ Free Radical-Induced DNA} Damage Assay. The prooxidant or antioxidant potential of nanoparticles was assessed through an $\mathrm{OH}$ free radical scavenging assay. When $\mathrm{OH}$ radicals attack DNA, the supercoiled form of DNA changes into an open circular form if there is a single-strand break. On the other hand, in the case of a double-strand break, a linear form is produced moving between the above two forms [49]. Our results showed that all gold nanoparticles were good oxidants, but when these particles were mixed with $\mathrm{H}_{2} \mathrm{O}_{2}$ and $\mathrm{FeSO}_{4}$, complete DNA damage was seen, demonstrating the neutral behavior of gold nanoparticles (Figure 3(d)A). Iron nanoparticles in prooxidant control showed light damage to DNA giving both open circular and supercoiled bands (i.e., single-strand break) (Figure 3(d)B). When these iron nanoparticles were mixed with $\mathrm{H}_{2} \mathrm{O}_{2}$ and $\mathrm{FeSO}_{4}$, they completely damaged DNA at all concentrations. This may be due to the release of iron from nanoparticles that have the potential to cause the conversion of $\mathrm{H}_{2} \mathrm{O}_{2}$ and superoxide anions to $\mathrm{OH}$ radicals. Furthermore, free iron ions can cause $\mathrm{OH}$-induced modifications of purine and pyrimidine and could give the surplus amount of iron, thus causing the production of highly reactive hydroxyl radicals by the Fenton 


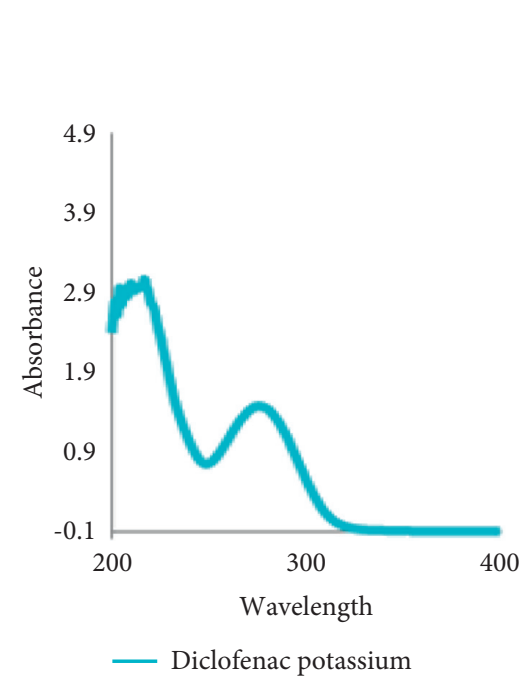

(a)

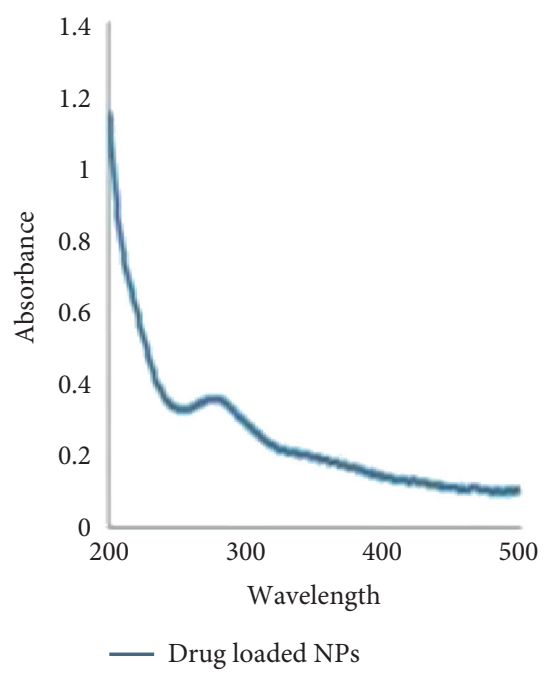

(d)

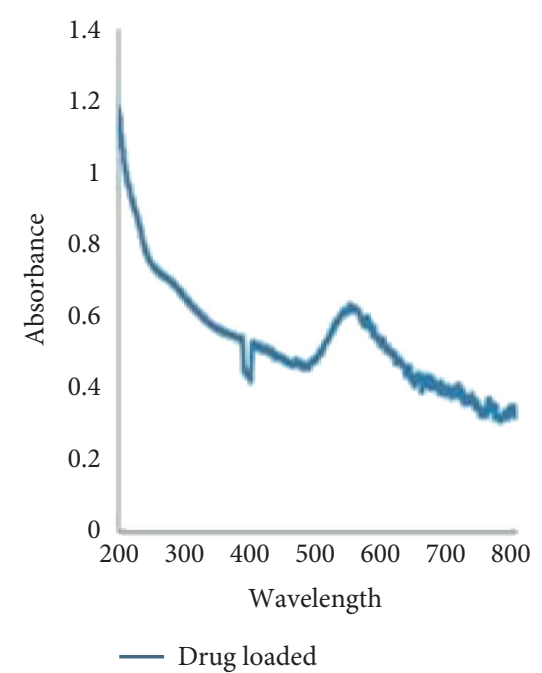

(c)

(b)

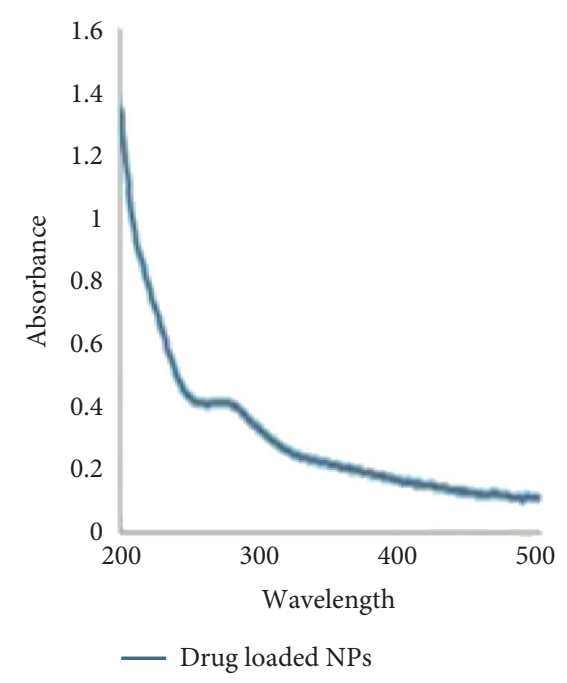

(e)

FIgURE 4: UV-visible spectra of diclofenac potassium and drug-loaded nanoparticles of (a) diclofenac potassium (DFP), (b) Syzygium cumini AuNPs, (c) Ficus microcarpa AuNPs, (d) Syzygium cumini FeNPs, (e) Ficus microcarpa FeNPs.

reaction [50]. We observed that the extracts of Phyllanthus emblica (at conc. of $1000 \mu \mathrm{g} / \mathrm{mL}$ and $100 \mu \mathrm{g} / \mathrm{mL}$ ), Rosa indica, Syzygium cumini, Mallotus philippensis, and Ficus microcarpa (only at conc. of $1000 \mu \mathrm{g} / \mathrm{mL}$ ), used a control, showed slight protection.

3.6. Analysis of Drug-Loaded Nanoparticles. Due to small size and good in vitro activities, AuNPs and FeNPs of Syzygium cumini and Ficus microcarpa were selected for drug loading. The highest percentage of drug loading was seen in Ficus microcarpa FeNPs, i.e., 65\%. After drug loading, supernatant (containing free drug) and pellet (containing drug-loaded nanoparticles) were compared with standard drug. UV-visible peak analysis indicated good folic acid attachment only in the case of FeNPs (Figure 4). The redshift (from $238 \mathrm{~nm}$ to $275 \mathrm{~nm}$ ) was seen only in the case of iron nanoparticles when they interacted with casein-folic acid conjugate. This may be because ligand attachment, as well as drug loading, depends on nanoparticle surface properties, such as structure and charge [51]. FTIR spectrum of drug-loaded nanoparticles was compared with DFP (Figure 5(e)). Ficus microcarpa diclofenac-loaded iron nanoparticles (with 65\% loading) showed two characteristic peaks of diclofenac potassium at $3285.54 \mathrm{~cm}^{-1}$ and $2920.81 \mathrm{~cm}^{-1}$ (Figure 5(d)). These peaks show the drug binding with phenols, alcohol, and carboxylic acids groups capped on the surface of nanoparticles. Ficus microcarpa gold nanoparticles and Syzygium cumini gold nanoparticles showed characteristic peaks of diclofenac at $2919.5 \mathrm{~cm}^{-1}$ and $2921.3 \mathrm{~cm}^{-1}$ (Figures 5(a) and 5(b)). Syzygium cumini iron nanoparticles showed no diclofenac peaks at all (Figure 5(c)). This may be due to the lowest diclofenac loading efficiency of Syzygium cumini iron nanoparticles, i.e., $27 \%$.

3.7. Anti-Inflammatory Activity. In vivo anti-inflammatory potential of AuNPs and FeNPs was assessed by carrageenaninduced rat hind paw edema test. Results showed that 


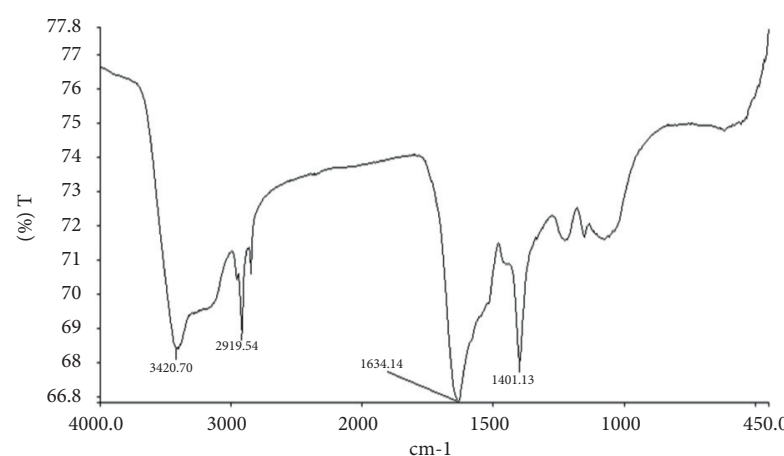

(a)

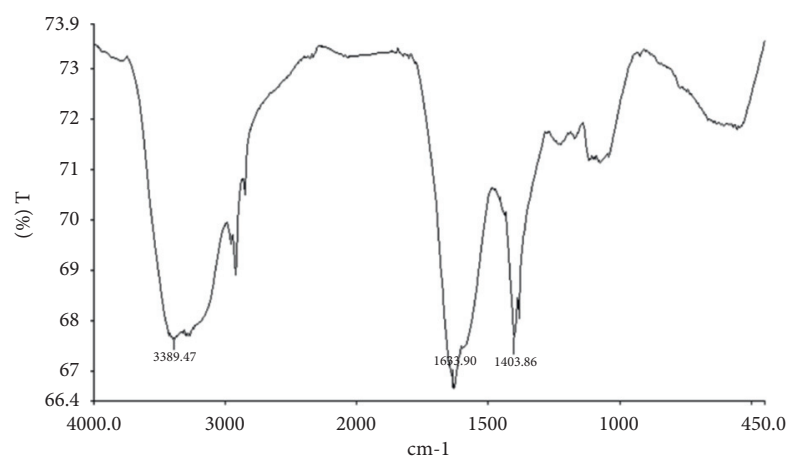

(c)

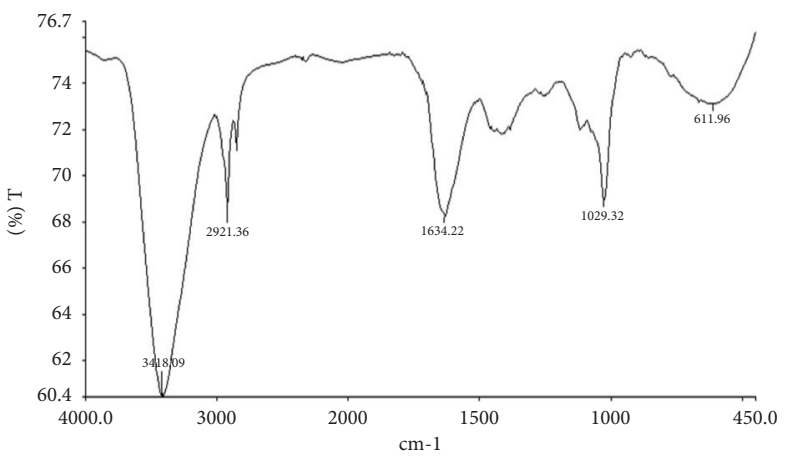

(b)

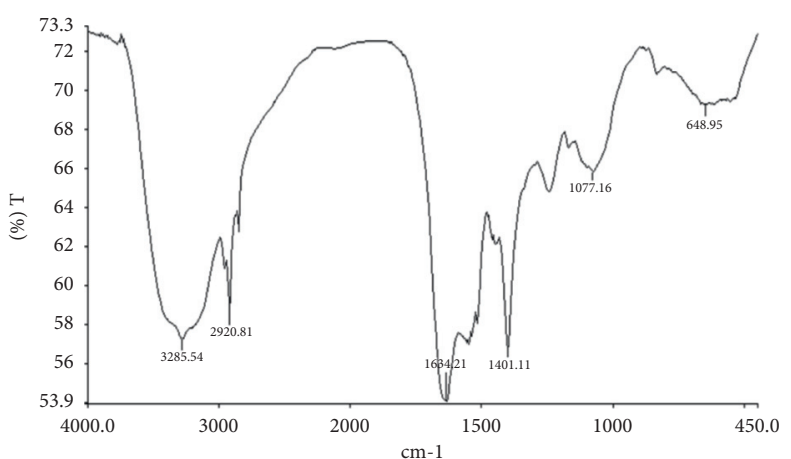

(d)

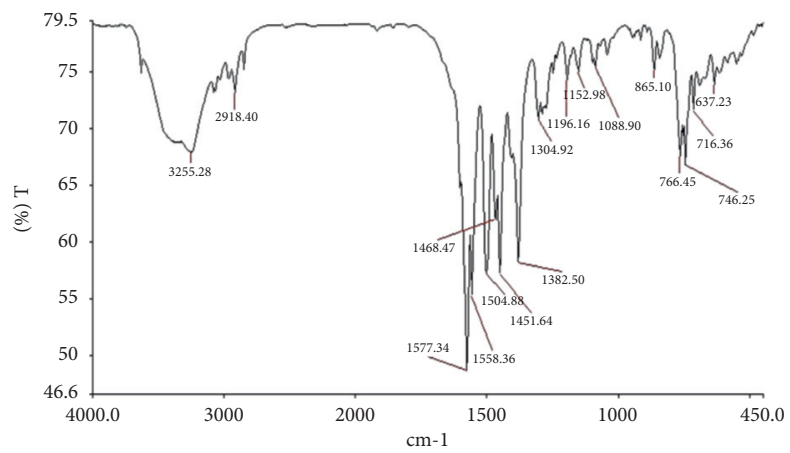

(e)

FIGURE 5: FTIR spectra of (a) Syzygium cumini diclofenac potassium loaded gold nanoparticles (AuNPs), (b) Ficus microcarpa diclofenac potassium loaded AuNPs, (c) Syzygium cumini diclofenac potassium loaded iron nanoparticles (FeNPs), (d) Ficus microcarpa diclofenac potassium loaded FeNPs, (e) diclofenac potassium (DFP).

Syzygium cumini gold nanoparticles exhibited strong antiinflammatory activity as compared to control (Figure 6). These particles might show anti-inflammatory effects by inducing the level of proinflammatory cytokines, i.e., TNF-alpha, which is the reported anti-inflammatory mechanism for gold nanoparticles [52]. This strong anti-inflammatory activity may be due to some capping agents of Syzygium cumini extract. Ficus microcarpa gold nanoparticles did not exhibit significant inhibition to edema. This might be because the generation of proinflammatory cytokines depends on the material and size of nanoparticles [53]. Iron nanoparticles exhibited less anti-inflammatory activity as compared to gold nanoparticles. Results of FeNPs are consistent with the previous studies; these particles are known to induce inflammation via oxidative stress [54]. The exact mechanism is not known but it may be because inflammatory response also depends on nanoparticle composition [55].

Diclofenac-loaded Ficus microcarpa gold nanoparticles have not shown any anti-inflammatory activity. Diclofenac-loaded Syzygium cumini gold nanoparticles exhibited less activity than Syzygium cumini gold nanoparticles (without any drug), which shows that either drug was not loaded properly or folic acid attachment to drug-loaded particles might cause such drastic change to nanoparticle surface that it could not reduce edema to such an extent. The same case was observed for drug-loaded Syzygium cumini iron nanoparticles. Ficus microcarpa drugloaded iron nanoparticles showed higher edema inhibition than DFP and Ficus microcarpa FeNPs (without any drug). These results correlate with the highest loading efficiency of Ficus microcarpa drug-loaded iron nanoparticles, i.e., 65\%. This 


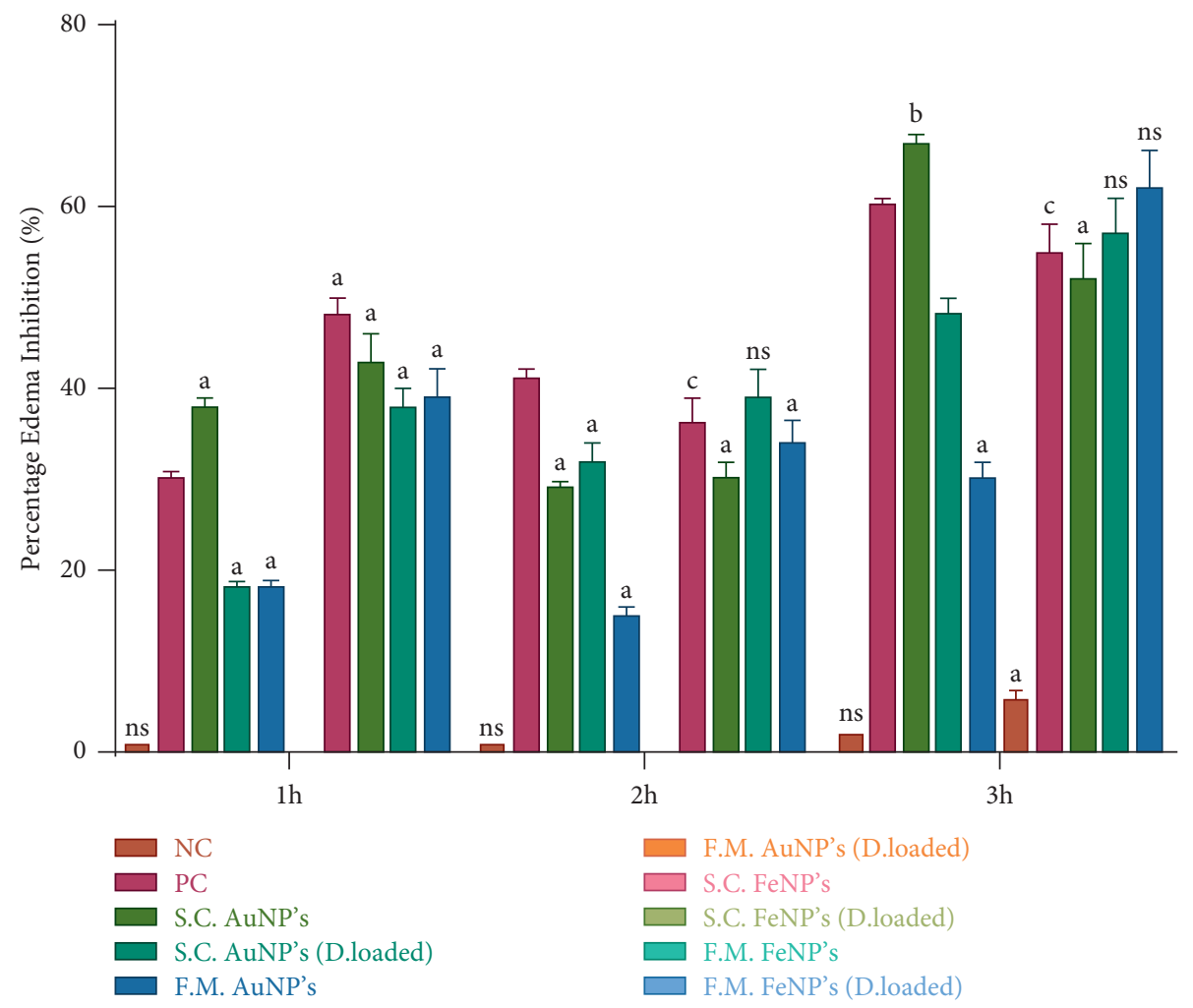

Figure 6: Percentage edema inhibition of different nanoparticles by carrageenan-induced rat paw edema test (S. cumini AuNPs: Syzygium cumini gold nanoparticles, S. cumini FeNPs: Syzygium cumini iron nanoparticles, F. microcarpa AuNPs: Ficus microcarpa gold nanoparticles, F. microcarpa FeNPs: Ficus microcarpa iron nanoparticles). Data represent the mean with statistical significance a: $p<0.001$, b: $p<0.01, \mathrm{c}: p<0.05$, ns: nonsignificance.

shows that diclofenac-loaded folic-acid-coupled iron nanoparticles can be used for drug delivery systems as they enhanced the effect of the drug possibly by lowering the side effects and increasing the specificity of the drug towards the target cell. The above results indicate the increase of anti-inflammatory activity and decrease in paw swelling over time. The highest anti-inflammatory activity was recorded at $3^{\text {rd }} \mathrm{h}$.

3.8. Anticoagulant Assay. The anticoagulant activity of nanoparticles was checked by the capillary tube method. Table 2 shows that all nanoparticles do not have anticoagulant activity as blood clotting time is decreased in all samples concerning negative control. These results are consistent with the reported findings that nanoparticles can find an escape from the normal defense system, rapidly enter the systemic circulation, and cause platelets aggregation [56]. Nanoparticles effect on platelets aggregation also depends on particle size, shape, and surface (i.e., electrical properties and surface charge). Nonsteroidal antiinflammatory drug (DFP) is known to inhibit platelet aggregation and increase bleeding time. In the present study, diclofenac-loaded nanoparticles exhibited a better blood coagulation effect as compared to control. This may be due to the attachment of DFP on the surface of the nanoparticles. However, it can be seen that diclofenac-loaded Ficus microcarpa iron nanoparticles (with 65\% drug loading efficiency) showed increased clotting time as compared to Ficus microcarpa iron nanoparticles (without diclofenac).
TABLE 2: Effect of nanoparticles on blood clotting time.

\begin{tabular}{lcc}
\hline SN & Sample & Clotting time (sec) \\
\hline 1 & Negative control & $101 \pm 1.15^{\mathrm{b}}$ \\
2 & S. cumini AuNPs & $35 \pm 7.5^{\mathrm{a}}$ \\
3 & S. cumini AuNPs (drug loaded) & $30 \pm 9.8^{\mathrm{b}}$ \\
4 & F. microcarpa AuNPs & $29 \pm 3.5^{\mathrm{b}}$ \\
5 & F. microcarpa AuNPs (drug loaded) & $29 \pm 7.9^{\mathrm{a}}$ \\
6 & S. cumini FeNPs & $47 \pm 7.5^{\mathrm{b}}$ \\
7 & S. cumini FeNPs (drug loaded) & $43 \pm 5.5^{\mathrm{b}}$ \\
8 & F. microcarpa FeNPs & $17 \pm 18.3^{\mathrm{a}}$ \\
9 & F. microcarpa FeNPs (drug loaded) & $30 \pm 24.4^{\mathrm{b}}$ \\
10 & Positive control & $12 \pm 1.2^{2}$ \\
\hline
\end{tabular}

Data represent the mean of triplicate measurements with statistical significance a: $p<0.001, b: p<0.01 ; \pm$ shows standard deviation. S. cumini AuNPs: Syzygium cumini gold nanoparticles, S. cumini FeNPs: Syzygium cumini iron nanoparticles, F. microcarpa AuNPs: Ficus microcarpa gold nanoparticles, F. microcarpa FeNPs: Ficus microcarpa iron nanoparticles.

\section{Conclusion}

In conclusion, an eco-friendly, green chemistry-based approach has been devised to synthesize metallic nanoparticles coupled with folic acid for targeted delivery of DFP to inflamed cells. The synthesized gold and iron nanoparticles were stable at refrigerated temperature and showed a small size range (i.e., less than $50 \mathrm{~nm}$ ). Both gold and iron nanoparticles proved to be good antibacterial agents against gram +ve and gram -ve bacteria. Among all synthesized 
nanoparticles, Phyllanthus emblica and Syzygium cumini synthesized iron nanoparticles served as DPPH free radical scavengers, while gold nanoparticles did not show antioxidant potential. Gold nanoparticles were protective while iron nanoparticles did not show any protection against DNA damage. Among gold and iron nanoparticles, only Syzygium cumini synthesized gold nanoparticles showed strong antiinflammatory potential. The biological activity of synthesized gold and iron nanoparticles was more than their corresponding salts and extracts. As a result, it is possible that these stable and nontoxic metallic nanoparticles can be used for targeted drug delivery and disease therapy.

\section{Data Availability}

The data used to support the findings of this study are included within the article.

\section{Ethical Approval}

Animals were housed at the Quaid-i-Azam University primate facility. The Institutional Ethics and Biosafety Committee approved the study design, and all safety precautions were taken to minimize animal suffering.

\section{Conflicts of Interest}

The authors declare no conflicts of interest.

\section{Acknowledgments}

The authors would like to extend their sincere appreciation to Taif University Researchers Supporting Project (no. TURSP-2020/309), Taif University, Taif, Saudi Arabia. The authors are also grateful to the Higher Education Commission of Pakistan for the support of this research work.

\section{References}

[1] M. Abhilash, "Potential applications of nanoparticles," International Journal of Pharma Bio Sciences, vol. 1, no. 1, 2010.

[2] M. A. Rabeea, M. N. Owaid, and R. F. Muslim, "Synthesis and characterization of silver nanoparticles by natural organic compounds extracted from Eucalyptus leaves and their role in the catalytic degradation of methylene blue dye," Songklanakarin Journal of Science and Technology, vol. 43, no. 1, pp. 14-23, 2021.

[3] S. O'Brien, L. Brus, and C. B. Murray, "Synthesis of monodisperse nanoparticles of barium titanate: toward a generalized strategy of oxide nanoparticle synthesis," Journal of the American Chemical Society, vol. 123, no. 48, pp. 12085-12086, 2001.

[4] G. A. Naeem, "Green synthesis of gold nanoparticles from coprinus comatus, agaricaceae, and the effect of ultraviolet irradiation on their characteristics," Walailak Journal of Science and Technology, vol. 18, no. 8, 2021.

[5] S. Iravani, "Green synthesis of metal nanoparticles using plants," Green Chemistry, vol. 13, no. 10, pp. 2638-2650, 2011.

[6] J. Banerjee, "Biosynthesis of silver nanoparticles from Syzygium cumini (L.) seed extract and evaluation of their in vitro antioxidant activities," Digest Journal of Nanomaterials and Biostructures, vol. 6, no. 3, pp. 961-968, 2011.
[7] P. Daisy and K. Saipriya, "Biochemical analysis of Cassia fistula aqueous extract and phytochemically synthesized gold nanoparticles as hypoglycemic treatment for diabetes mellitus," International Journal of Nanomedicine, vol. 7, pp. 1189-1202, 2012.

[8] V. Baskaralingam, "Green synthesis of Silver nanoparticles through Calotropis gigantea leaf extracts and evaluation of antibacterial activity against Vibrio alginolyticus," Nanotechnology Development, vol. 2, no. 1, 2012.

[9] M. A. Dheyab, M. N. Owaid, M. A. Rabeea, A. A. Aziz, and M. S. Jameel, "Mycosynthesis of gold nanoparticles by the Portabello mushroom extract, Agaricaceae, and their efficacy for decolorization of Azo dye," Environmental Nanotechnology, Monitoring \& Management, vol. 14, Article ID 100312, 2020.

[10] K. S. Mukunthan and S. Balaji, "Cashew apple juice (anacardium occidentaleL.) speeds up the synthesis of silver nanoparticles," International Journal of Green Nanotechnology, vol. 4, no. 2, pp. 71-79, 2012.

[11] S. Y. Abdul-Hadi, M. N. Owaid, M. A. Rabeea, A. Abdul Aziz, and M. S. Jameel, "Rapid mycosynthesis and characterization of phenols-capped crystal gold nanoparticles from Ganoderma applanatum, Ganodermataceae," Biocatalysis and Agricultural Biotechnology, vol. 27, Article ID 101683, 2020.

[12] M. A. Rabeea, M. N. Owaid, A. A. Aziz, M. S. Jameel, and M. A. Dheyab, "Mycosynthesis of gold nanoparticles using the extract of Flammulina velutipes, Physalacriaceae, and their efficacy for decolorization of methylene blue," Journal of Environmental Chemical Engineering, vol. 8, no. 3, Article ID 103841, 2020.

[13] V. Kumar and S. K. Yadav, "Plant-mediated synthesis of silver and gold nanoparticles and their applications," Journal of Chemical Technology \& Biotechnology, vol. 84, no. 2, pp. 151-157, 2009.

[14] S. P. Chandran, M. Chaudhary, R. Pasricha, A. Ahmad, and M. Sastry, "Synthesis of gold nanotriangles and silver nanoparticles using Aloe vera plant extract," Biotechnology Progress, vol. 22, no. 2, pp. 577-583, 2006.

[15] N. Muniyappan and N. S. Nagarajan, "Green synthesis of gold nanoparticles using Curcuma pseudomontana essential oil, its biological activity and cytotoxicity against human ductal breast carcinoma cells T47D," Journal of Environmental Chemical Engineering, vol. 2, no. 4, pp. 2037-2044, 2014.

[16] S. Patil and R. Chandrasekaran, "Biogenic nanoparticles: a comprehensive perspective in synthesis, characterization, application and its challenges," Journal of Genetic Engineering and Biotechnology, vol. 18, no. 1, p. 67, 2020.

[17] G. K. Dang, R. R. Parekar, S. K. Kamat, A. M. Scindia, and N. N. Rege, "Antiinflammatory activity of Phyllanthus emblica, Plumbago zeylanica and Cyperus rotundus in acute models of inflammation," Phytotherapy Research, vol. 25, no. 6, pp. 904-908, 2011.

[18] E. Nicolis, I. Lampronti, M. C. Dechecchi et al., "Pyrogallol, an active compound from the medicinal plant Emblica officinalis, regulates expression of pro-inflammatory genes in bronchial epithelial cells," International Immunopharmacology, vol. 8, no. 12, pp. 1672-1680, 2008.

[19] J. K. Jose, G. Kuttan, and R. Kuttan, "Antitumour activity of Emblica officinalis,” Journal of Ethnopharmacology, vol. 75, no. 2-3, pp. 65-69, 2001.

[20] B. D. Hiraganahalli, V. C Chinampudur, S Dethe et al., "Hepatoprotective and antioxidant activity of standardized herbal extracts," Pharmacognosy Magazine, vol. 8, no. 30, pp. 116-123, 2012. 
[21] M. M. Shivananjappa and M. K. Joshi, "Influence ofEmblica officinalisaqueous extract on growth and antioxidant defense system of human hepatoma cell line (HepG2)," Pharmaceutical Biology, vol. 50, no. 4, pp. 497-505, 2012.

[22] L. Anila and N. R. Vijayalakshmi, "Flavonoids from Emblica officinalis and Mangifera indica-effectiveness for dyslipidemia," Journal of Ethnopharmacology, vol. 79, no. 1, pp. 81-87, 2002.

[23] M. Doble, K. Rollins, and A. Kumar, Green Chemistry and Engineering, Academic Press, Cambridge, MA, USA, 2010.

[24] J. Singh, T. Dutta, K.-H. Kim, M. Rawat, P. Samddar, and P. Kumar, "“Green" synthesis of metals and their oxide nanoparticles: applications for environmental remediation," Journal of Nanobiotechnology, vol. 16, no. 1, p. 84, 2018.

[25] F. A. Larik, "New 1-octanoyl-3-aryl thiourea derivatives: solvent-free synthesis, characterization and multi-target biological activities," Bangladesh Journal of Pharmacology, vol. 11, no. 4, 2016.

[26] M. Z. Bhatti, A. Ali, A. Ahmad, A. Saeed, and S. A. Malik, "Antioxidant and phytochemical analysis of Ranunculus arvensis L. extracts," BMC Research Notes, vol. 8, no. 1, p. 279, 2015.

[27] H. Ismail, B. Mirza, I.-u. Haq, M. Shabbir, Z. Akhter, and A. Basharat, "Synthesis, characterization, and pharmacological evaluation of selected aromatic amines," Journal of Chemistry, vol. 2015, Article ID 465286, 9 pages, 2015.

[28] M. Ganeshkumar, M. Sathishkumar, T. Ponrasu, M. G. Dinesh, and L. Suguna, "Spontaneous ultra fast synthesis of gold nanoparticles using Punica granatum for cancer targeted drug delivery," Colloids and Surfaces B: Biointerfaces, vol. 106, pp. 208-216, 2013.

[29] W. K. Kayani, E. Dilshad, T. Ahmed, H. Ismail, and B. Mirza, "Evaluation of Ajuga bracteosa for antioxidant, anti-inflammatory, analgesic, antidepressant and anticoagulant activities," BMC Complementary and Alternative Medicine, vol. 16, no. 1 , p. 375,2016

[30] H. Ismail and B. Mirza, "Evaluation of analgesic, anti-inflammatory, anti-depressant and anti-coagulant properties of Lactuca sativa (CV. Grand Rapids) plant tissues and cell suspension in rats," BMC Complementary and Alternative Medicine, vol. 15, no. 1, pp. 199-203, 2015.

[31] S. Lee, W. Lee, J.-S. Bae, and E. Ma, "Synthesis and in vitro and in vivo anticoagulant and antiplatelet activities of amidinoand non-amidinobenzamides," Molecules, vol. 21, no. 5, pp. 676-685, 2016.

[32] N. Akhtar, I.-u. Ihsan-ul-Haq, and B. Mirza, "Phytochemical analysis and comprehensive evaluation of antimicrobial and antioxidant properties of 61 medicinal plant species," Arabian Journal of Chemistry, vol. 11, no. 8, pp. 1223-1235, 2018.

[33] M. Amin, F. Anwar, M. R. S. A. Janjua, M. A. Iqbal, and U. Rashid, "Green synthesis of silver nanoparticles through reduction with Solanum xanthocarpum L. berry extract: characterization, antimicrobial and urease inhibitory activities against Helicobacter pylori," International Journal of Molecular Sciences, vol. 13, no. 8, pp. 9923-9941, 2012.

[34] M. S. Jabir, U. M. Nayef, W. K. Abdulkadhim et al., "Fe3O4 nanoparticles capped with PEG induce apoptosis in breast cancer AMJ13 cells via mitochondrial damage and reduction of NF- $\kappa \mathrm{B}$ translocation," Journal of Inorganic and Organometallic Polymers and Materials, vol. 31, no. 3, pp. 1241-1259, 2020.

[35] M. Jabir, U. I. Sahib, Z. Taqi et al., "Linalool-loaded glutathione-modified gold nanoparticles conjugated with CALNN peptide as apoptosis inducer and NF- $\kappa \mathrm{B}$ translocation inhibitor in SKOV-3 cell line," International Journal of Nanomedicine, vol. 15, pp. 9025-9047, 2020.

[36] W. Wu, Q. He, and C. Jiang, "Magnetic iron oxide nanoparticles: synthesis and surface functionalization strategies," Nanoscale Research Letters, vol. 3, no. 11, pp. 397-415, 2008.

[37] S. Al-Musawi, "Antibacterial activity of honey/chitosan nanofibers loaded with capsaicin and gold nanoparticles for wound dressing," Molecules, vol. 25, no. 20, 2020.

[38] S. A. Khan, S. Shahid, and C. S. Lee, "Green synthesis of gold and silver nanoparticles using leaf extract of clerodendrum inerme; characterization, antimicrobial, and antioxidant activities," Biomolecules, vol. 10, no. 6, 2020.

[39] A. G. Al-Dulimi, A. Z. Al-Saffar, and G. M. Sulaiman, "Enhanced cellular uptake and anti-cancer potentials of gold nanoparticles conjugated with cell penetration peptide against lung cancer cells," IOP Conference Series: Materials Science and Engineering, vol. 928, Article ID 062025, 2020.

[40] B. Naveena and S. Prakash, "Biological synthesis of gold nanoparticles using marine algae gracilaria corticata and its application as a potent antimicrobial and antioxidant agent," 2013.

[41] W. Pajerski, "Attachment efficiency of gold nanoparticles by Gram-positive and Gram-negative bacterial strains governed by surface charges," Journal of Nanoparticle Research, vol. 21, no. 8, 2019.

[42] S. Veeraapandian, S. N. Sawant, and M. Doble, "Antibacterial and antioxidant activity of protein capped silver and gold nanoparticles synthesized with Escherichia coli," Journal of Biomedical Nanotechnology, vol. 8, no. 1, pp. 140-148, 2012.

[43] O. Al Rugaie, "Gold nanoparticles and graphene oxide flakes synergistic partaking in cytosolic bactericidal augmentation: role of ROS and NOX2 activity," Microorganisms, vol. 9, no. 1, 2021.

[44] N. Tran, A Mir, D Mallik, A Sinha, S Nayar, and T. J Webster, "Bactericidal effect of iron oxide nanoparticles on Staphylococcus aureus," International Journal of Nanomedicine, vol. 5, pp. 277-283, 2010.

[45] S. Das, S. Diyali, G. Vinothini et al., "Synthesis, morphological analysis, antibacterial activity of iron oxide nanoparticles and the cytotoxic effect on lung cancer cell line," Heliyon, vol. 6, no. 9, Article ID e04953, 2020.

[46] C. Ramamurthy, M. Padma, I. D. mariya samadanam et al., "The extra cellular synthesis of gold and silver nanoparticles and their free radical scavenging and antibacterial properties," Colloids and Surfaces B: Biointerfaces, vol. 102, pp. 808-815, 2013.

[47] C. Falugi, M. G. Aluigi, M. C. Chiantore et al., "Toxicity of metal oxide nanoparticles in immune cells of the sea urchin," Marine Environmental Research, vol. 76, pp. 114-121, 2012.

[48] C. Gambardella, T. Mesarič, T. Milivojević et al., "Effects of selected metal oxide nanoparticles on Artemia salina larvae: evaluation of mortality and behavioural and biochemical responses," Environmental Monitoring and Assessment, vol. 186, no. 7, pp. 4249-4259, 2014.

[49] A. T. Chaviara, E. E. Kioseoglou, A. A. Pantazaki et al., "DNA interaction studies and evaluation of biological activity of homo- and hetero-trihalide mononuclear $\mathrm{Cu}(\mathrm{II})$ Schiff base complexes. Quantitative structure-activity relationships," Journal of Inorganic Biochemistry, vol. 102, no. 9, pp. 17491764, 2008.

[50] M. Valko, D. Leibfritz, J. Moncol, M. T. D. Cronin, M. Mazur, and J. Telser, "Free radicals and antioxidants in normal physiological functions and human disease," The 
International Journal of Biochemistry \& Cell Biology, vol. 39, no. 1, pp. 44-84, 2007.

[51] K. B. Narayanan and N. Sakthivel, "Biological synthesis of metal nanoparticles by microbes," Advances in Colloid and Interface Science, vol. 156, no. 1-2, pp. 1-13, 2010.

[52] B. Rothen-Rutishauser, C. Mühlfeld, F. Blank, C. Musso, and P. Gehr, "Translocation of particles and inflammatory responses after exposure to fine particles and nanoparticles in an epithelial airway model," Particle and Fibre Toxicology, vol. 4, no. 1, p. 9, 2007.

[53] M. V. D. Z. Park, A. M. Neigh, J. P. Vermeulen et al., "The effect of particle size on the cytotoxicity, inflammation, developmental toxicity and genotoxicity of silver nanoparticles," Biomaterials, vol. 32, no. 36, pp. 9810-9817, 2011.

[54] M.-T. Zhu, B. Wang, Y. Wang et al., "Endothelial dysfunction and inflammation induced by iron oxide nanoparticle exposure: risk factors for early atherosclerosis," Toxicology Letters, vol. 203, no. 2, pp. 162-171, 2011.

[55] A. Gojova, B. Guo, R. S. Kota, J. C. Rutledge, I. M. Kennedy, and A. I. Barakat, "Induction of inflammation in vascular endothelial cells by metal oxide nanoparticles: effect of particle composition," Environmental Health Perspectives, vol. 115, no. 3, pp. 403-409, 2007.

[56] J. P. Berry, B Arnoux, G Stanislas, P Galle, and J Chretien, “A microanalytic study of particles transport across the alveoli: role of blood platelets," Biomedicine/(publiee pour l'A.A.I.C.I.G.), vol. 27, no. 9-10, pp. 354-357, 1977. 